If using this paper, please cite as:

Pournader, M., A. Kach, S.H. Razavi Hajiagha and A. Emrouznejad (2017), Investigating the Impact of Behavioral Factors on Supply Network Efficiency: Insights from Banking's Corporate Bond Networks, Annals of Operations Research, Accepted.

Final version will be avilavle at: https://link.springer.com/article/10.1007\%2Fs10479-017-2457-8.

\title{
Investigating the Impact of Behavioral Factors on Supply Network Efficiency: Insights from Banking's Corporate Bond Networks
}

Mehrdokht Pournader ${ }^{1 *}$, Andrew Kach ${ }^{2}$, Seyed Hossein Razavi Hajiagha ${ }^{3}$, Ali Emrouznejad ${ }^{4}$

${ }^{1}$ Macquarie Graduate School of Management, Macquarie University, Macquarie Park, NSW 2109, Australia, mehrdokht.pournader@hdr.mq.edu.au

${ }^{2}$ Atkinson Graduate School of Management, Willamette University, 900 State Street, Salem, OR 97301, apkach@willamette.edu

${ }^{3}$ Department of Management, Khatam University, Hakim A'zam Alley, North Shiraz Ave., Mollasadra Street, Tehran, Iran, sh.razavi@st.atu.ac.ir

${ }^{4}$ Professor and Chair in business Analytics, Aston Business School, Aston University, Birmingham B4 7ET, UK, a.emrouznejad@ aston.ac.uk

\begin{abstract}
This paper highlights the role of behavioral factors for efficiency measurement in supply networks. To this aim, behavioral issues are investigated among interrelations between decision makers involved in corporate bond service networks. The corporate bond network was considered in three consecutive stages, where each stage represents the relations between two members of the network: issuer-underwriter, underwriter-bank, and bank-investor. Adopting a multi-method approach, we collected behavioral data by conducting semi-structured interviews and applying the critical incident technique. Financial and behavioral data, collected from each
\end{abstract}

*Macquarie Graduate School of Management, Macquarie University, Macquarie Park, NSW 2109, Australia, Email: mehrdokht.pournader@hdr.mq.edu.au

Phone: +61298507800 \& Fax: +61298508630 
stage in 20 corporate bond networks, were analyzed using fuzzy network data envelopment analysis to obtain overall and stage-wise efficiency scores for each network. Sensitivity analyzes of the findings revealed inefficiencies in the relations between underwriters-issuers, banks-underwriters, and banks-investors stemming from certain behavioral factors. The results show that incorporating behavioral factors provides a better means of efficiency measurement in supply networks.

Keywords: Behavioural operations, corporate bonds service network, network data envelopment analysis, fuzzy sets

\section{Introduction}

Although the subject of behavior has long been popular among organizational, managerial, and business fields of study (e.g., strategy, marketing, economics, and finance), certain aspects of behavior have been introduced quite recently into the operations and supply chain management domain for modeling relevant real-world situations (Bendoly et al. 2010; Croson et al. 2013). Behavioral factors, which reside in behavioral irrationalities embedded in individuals' choices, social preferences, or bounded rationalities (Özer and Zheng 2012), can result in biased judgments and erroneous decision making. Understanding these behavioral irrationalities is essential if we are to manage them effectively in supply chains (Carter et al. 2007). Moreover, it has been argued that behavioral factors play an important role in causing several supply chain-related problems (e.g., bullwhip effects), even when almost all other sources of operational errors are eliminated (Wan and Evers 2011; Croson et al. 2014).

Including behavioral factors in supply chain decision-making models results in better predictability and more effective operating systems (Giannoccaro and Ilaria 2013). The latter could especially enhance the predictability of empirical and analytical models that aim to improve decision-making processes (Hämäläinen et al. 2013; Tiwana et al. 2007). However, 
such approaches are generally overlooked because the aforementioned analytical models are considered too complex to solve (Mingers 2011). Nonetheless, Bendoly et al. (2006), p. 739 argue that, despite the seemingly different assumptions between mathematical models of operations and methods used for studying human behavior, "the two methodologies can complement each other with each positing useful directions of inquiry for the other". Bendoly et al. (2015) also argue that considering the bounded rationalities of decision makers in mathematical models of operations opens up new avenues and opportunities to better comprehend and manage operations within a given context. That said, managers and researchers alike would benefit from a greater understanding of how behavioral factors play a role in decision-making processes in supply networks and, likewise, the effect they have on supply network efficiency.

Following the call for "high-quality research that is able to influence both thought and practice" surrounding the "human factor" in the field of supply chain management Fawcett et al. (2011), p. 119, we focused on including behavioral factors in data envelopment analysis (DEA) models for measuring efficiency in supply networks. DEA models encompass a wide spectrum of applications in industry and services to tackle various aspects of efficiency measurement in supply networks (e.g., Chen and Yan 2011; Wu and Olson 2009; Talluri et al. 2013). Our study looked particularly at supply networks within the banking industry, describing a three-stage supply chain process for issuing corporate bonds. Our motivation to investigate the banking industry was twofold. First, of all business sectors, the banking industry is believed to have the highest rate of application of DEA models (Liu et al. 2013; $\underline{\text { Wu and }}$ Birge 2012), offering established and validated approaches to model building and efficiency measurement in this context (Paradi and Zhu 2013). Second, close interactions between decision makers in the banking industry and corporate bond networks during the bond issuing and underwriting processes could potentially expose this network to substantial behavioral 
risks. Thereby, the purpose of this study was to provide evidence of how behavioral factors influence the efficiency of supply networks by considering the efficiency of both operational and decision-making processes throughout different stages of a supply network, and by leveraging a multi-method approach that encompassed both semi-structured interviews and DEA.

The remainder of this study is organized as follows. Next, we review the literature on the application of behavioral sciences in supply networks, focusing specifically on several behavioral misconducts and their adverse consequences in corporate bond service networks. The summary of the application of network DEA in different industrial and service contexts in the literature review section leads to description of a fuzzy network DEA model developed for the three-stage corporate bond network. In the methodology section we also explain the application of semi-structured interviews and critical incident technique to collect data related to behavioral factors in the corporate bond network. We then incorporate both behavioral and financial data into the fuzzy network DEA model, discussing the numerical outcomes of applying the proposed model to the banking industry of Iran, and examining the robustness of the results. Finally, we summarize the highlights of the study, outline its limitations and note avenues for future research.

\section{Literature review}

The study of behavioral issues in operations and supply chain management discourse is an emerging, multi-disciplinary field that is gaining increasing momentum (Bendoly et al. 2010; Knemeyer and Naylor 2011). One of the main reasons for this growing interest is that current models of real-world processes often fail to reflect human behavior, despite being one of the main drivers in operating systems (Giannoccaro and Ilaria 2013; Bendoly et al. 2015). Studying behavioral factors in the context of supply chains and supply networks is described as "the 
study of how judgment in supply management decision-making deviates from the assumptions of homo economicus" (Carter et al. 2007, p. 634). Investigating behavioral factors associated with decision-making processes within the context of inventory management (e.g., newsvendor problem (Su 2008; Nagarajan and Shechter 2014), bullwhip effects, and supply line underweighting (N. M. Wang et al. 2014; Croson et al. 2014)) has helped further explain deviations in efficiency that could not be described from taking a solely operational point of view.

Research into behavioral operations and supply chain management has offered opportunities for investigating decision makers' behavior, mostly based on cognitive psychology (Gino and Pisano 2008; Katsikopoulos and Gigerenzer 2013). For instance, loss aversion and risk aversion biases have been used primarily for inventory management problems such as the newsvendor problem to model managers' decision-making behavior (Wang and Webster 2009; Agrawal and Seshadri 2000). Studies have also investigated other types of cognitive biases, or even more general estimations of cognitive abilities of decision makers, and their impact on supply chain-related operations (Wu and Chen 2014; Narayanan and Moritz 2015). Some researchers have studied the effect of trust between members of supply chains (Özer et al. 2014; Read et al. 2014). Others have emphasized psychological aspects such as social psychology, group dynamics, or system dynamics in the context of behavioral operations and supply chain management (Bendoly et al. 2010; Bendoly 2014). The breadth of previous research illustrates that behavioral issues can affect efficiency in supply networks either at the level of individual decision makers or through their interactions with other individuals, groups, or even organizations. While it is impossible to capture all the behavioral facets for a specific context, we next propose several decision making-related scenarios in corporate bond networks in which certain behavioral anomalies could occur and have an adverse effect on tier-specific and/or overall efficiency of the network. 


\subsection{Behavioral Factors Emerging and Propagating in the Corporate Bond Network}

The corporate bond underwriting and issuance network consists of corporate clients as "issuers", investment banks or corporate banks as "underwriters", and "investors" as buyers of the bonds. Underwriters and commercial banks provide bonds issuing and underwriting services such as insurance for the unsold bonds and other types of services associated with pricing, marketing, documenting, and selling the bonds (Yasuda 2005, 2007). For their existing corporate clients, commercial banks opt for either their own corporate banking division or investment bank(s), or both, as underwriter(s) of corporate bonds.

However, several behavioral factors involved in the bilateral relations of network members could adversely affect the efficiency of operations within the network. For instance, in underwriter-issuer relations, different types of risks might arise if there is no previous history of constructive and collaborative relations between the bank and the corporate client. According to goal-setting theory (Locke and Latham 2002; Latham and Locke 1991), when building up good relations with clients is not a unanimously accepted goal among employees, there is insufficient motivation in the organization to put much effort and investment into strengthening relations with corporate customers. Even if banks accept specific and detailed goals regarding how corporate clients should be treated, the absence of salient and timely control mechanisms (i.e., Control Theory; (Bandura 2001, 1989) could fail to regulate the bank employees' behavior toward their corporate clients, leading to diminishing quality of services for clients and deteriorating relations between bank and client. Subsequently, clients are prone to assume (Mussweiler and Strack 2001; Tversky and Kahneman 1974) that further similar collaborations with the bank, including bonds underwriting and issuance, could yield the same undesirable results. This lack of trust between bank and client imposes additional costs on the bank to improve relations with the corporate client (Friend and Johnson 2014). 
The efficiency of the underwriting process also depends upon how the underwriter and the bank interact. A commercial bank's decision makers may choose an underwriter based on financial incentives; however, a number of behavioral factors could also come into play. First, both opting for an external investment bank as an underwriter and lack of trust between the bank and the investment bank would increase the bank's supervisory costs in eliminating any opportunistic behavior by the investment bank (Villena et al. 2011; Wathne and Heide 2000). The likely opportunistic behavior of the investment bank as the supplier of financial services could be reflected in the investment bank offering superior services or significant discounts to the issuer. Second, banks' decision makers might overestimate (Moore and Healy 2008; Bazerman and Moore 2012) the ability of the underwriter (especially their own corporate banking division) to provide quality services to their corporate clients. This overestimation might result in poor-quality services, customer dissatisfaction, and unsold bonds.

Bank-investor relations are also subject to risks from behavioral factors. Considering lossaversion bias, for instance (Kahneman et al. 1991), the behavior of a bank's decision makers toward investors could depend on how these decision makers define and perceive losses and gains in their relations with issuers. Corporate banks that are making inroads into the corporate bonds market usually tend to charge issuers with lower fees for the costs of underwriting and issuance services (Yasuda 2005; Gande et al. 1999), with the aim of building good relations with existing issuers and to avoid losing their existing corporate clients at any cost. However, these generous offerings might subsequently culminate in charging the investors higher prices for bonds to compensate for any financial losses (Yasuda 2007). Moreover, banks that are reluctant to lose their corporate clients at any cost might misuse their reputation in certifying the issuers' quality of bonds for less informed investors (Andres et al. 2014; Mathis et al. 2009). Such issues could affect investors' trust and willingness to purchase the bonds. 
Given the complexity of decision-making processes in real-world supply networks (e.g., corporate bond network), behavioral misconduct can extend beyond what has been discussed thus far. However, irrespective of their origin, poor-quality relations (e.g., lack of trust) arising from inadequate decision making could adversely affect the overall efficiency in supply networks. Hence, in the remaining sections of this manuscript, and more explicitly in conducting the case study, we adopt a more general view of behavioral issues in corporate bond networks, addressing how the "quality of relations" between supply network members can enhance efficiency.

\subsection{DEA and Network DEA in Banking Industry}

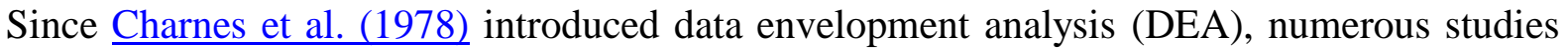
have used DEA, either singly or in combination with mathematical and/or statistical models, to measure relative efficiency of decision making units (DMUs) (Emrouznejad et al. 2008). DEA has been widely applied to measure efficiency in certain tiers or in the overall processes of supply chains (Liang et al. 2006; Yang et al. 2011). However, conventional DEA models do not consider the internal processes of DMUs; rather, they treat the system as a "black box". The network DEA model (Fare and Grosskopf 2000), an alternative to the black box model, enables managers to identify sources of inefficiencies in different stages of a network ( $\underline{\text { Kao and }}$

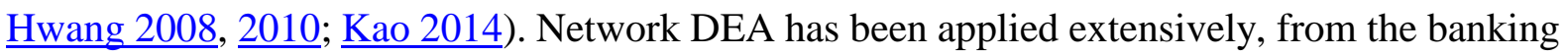
industry (e.g., Lozano 2015; Matthews 2013; Akther et al. 2013) to other industrial and services sectors (Mirhedayatian et al. 2014; Moreno and Lozano 2014; Vaz et al. 2010). Several recent studies have applied network DEA to the banking industry, measuring the efficiency of commercial banks: Akther et al. (2013) evaluated the efficiency of 21 commercial banks in Bangladesh in a two-staged network using the slacks-based inefficiency measure; Matthews $\underline{(2013)}$ developed a three-stage network slacks-based DEA framework that incorporated risk 
measures (i.e., financial and human resources-related risks) and non-profit loans to evaluate the efficiency of 15 domestic and commercial banks and four foreign banks in China; and $\underline{\mathrm{K}}$.

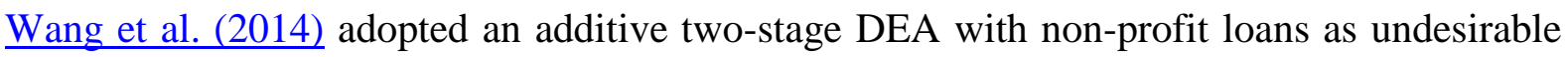
outputs to measure the efficiency of 16 main Chinese commercial banks, identifying several factors that improve efficiency in this sector.

Despite focusing on commercial banking, our study differs from the above in several ways. First, we did not limit the inputs and outputs of the corporate bond network model to merely tangible financial criteria; rather, we included the behavioral issues that might arise in this network, indicated by the "quality of relations" between each of the members in this network. Second, we considered only those processes related to issuing and underwriting bonds (excluding loans and deposits) by commercial banks. In this way we adopted a holistic view that incorporates all the players (i.e., issuer, underwriter, bank, and investors) within the corporate bond network as one single DMU.

\section{Methodology}

We adopted a multi-method approach using both quantitative and qualitative research methods to capture operational and decision making-related inefficiencies in the corporate bond network. Multi-method approaches apply multiple methodologies from the same or different disciplines and are ideal for studying a phenomenon and understanding its complexities (Sanders and Wagner 2011; Boyer and Swink 2008). Indeed, the increased rigor and reliability of adopting multi-method approaches results in "greater insights into research problems, reduction in the myopic, disciplined-based perspective, and greater potential for innovative SCM [Supply Chain Management] breakthroughs" (Sanders and Wagner (2011), p. 318. Similarly, combining several research methodologies such as survey, archival, behavioral, and case studies allows a deeper understanding of the phenomenon and increases the practical 
contributions of the research (Fawcett and Waller, 2011). In this section, we first use DEA modeling as a quantitative method to model all operational and behavioral factors that could affect efficiency in the corporate bond network. We then discuss the case, further describing the semi-structured interview and critical incident technique used to gather in-depth information about the underlying behavioral factors affecting the quality of relations within this network.

\subsection{Network DEA Model of the Corporate Bond Network}

Figure 1 presents the three stages in the corporate bond network and their associated inputs, outputs, and intermediary inputs/outputs. We aimed to measure technical efficiency instead of cost or allocative efficiency of the corporate bond network. To this end, we adopted the frequently used "intermediation approach" to assign interest expenses and non-interest expenses as inputs, and interest income and non-interest income as outputs (for more information see, Fethi and Pasiouras 2010). Given the dynamics of the corporate bond network and the exclusion of interest incomes (i.e. loans and deposits), we defined several non-interest expenses and non-interest incomes in the three stages of the corporate bond network as inputs and outputs.

Insert Figure 1 about here

As shown in Figure 1, personnel expenses (PE) $\left(x_{11}, x_{21}\right)$ and various other operational expenses (OOE) $\left(x_{12}, x_{22}\right)$ are used separately by the bank and underwriter in both Stage I and Stage II to yield referrals for bond underwriting and issuance (NoF) $\left(z_{1}\right)$ and to issue bonds (NV) $\left(z_{2}\right)$. Other operational expenses for marketing and selling bonds (OOE) $\left(x_{31}\right)$ in Stage III are inputs to produce final non-interest incomes of the network, including proportion of bonds sold to total bonds (SBT) $\left(y_{31}\right)$ and net fees and commissions (NFC) $\left(y_{32}\right)$. Depending 
on the quality of relations between network members, hidden costs of deteriorating relations and lack of trust in the network might also be considered, although these are not traditionally captured as a form of non-interest expenses. We therefore added the quality of bilateral relations $(\mathrm{QoR})$ between underwriter-issuer $\left(\tilde{x}_{13}\right)$, bank-underwriter $\left(\tilde{x}_{23}\right)$, and bank-investors $\left(\tilde{x}_{32}\right)$ as the additional inputs to the three stages in Figure 1, illustrated by dotted lines. Since there are no financial records or tangible measures to assess these behavioral inputs, and there are varying levels of uncertainties associated with them when evaluated by decision makers, we applied fuzzy sets theory to include quality of bilateral relations in our network DEA model. The " $"$ sign in the figure shows that the variables representing QoR in three stages of the corporate bond network are associated with some level of uncertainty.

Following Kao (2009) and Fare et al. (1989), the overall efficiency of the corporate bond network (Figure 1) for $\mathrm{DMU}_{\mathrm{k}}$ using the network DEA is formulated in model (1):

$$
E_{k}=\operatorname{Max} \frac{u_{31} y_{31}^{k}+u_{32} y_{32}^{k}}{\sum_{i=1}^{2}\left(v_{1 i} x_{1 i}^{k}+v_{2 i} x_{2 i}^{k}\right)+v_{13} \tilde{x}_{13}^{k}+v_{23} \tilde{x}_{23}^{k}+v_{31} x_{31}^{k}+v_{32} \tilde{x}_{32}^{k}}
$$

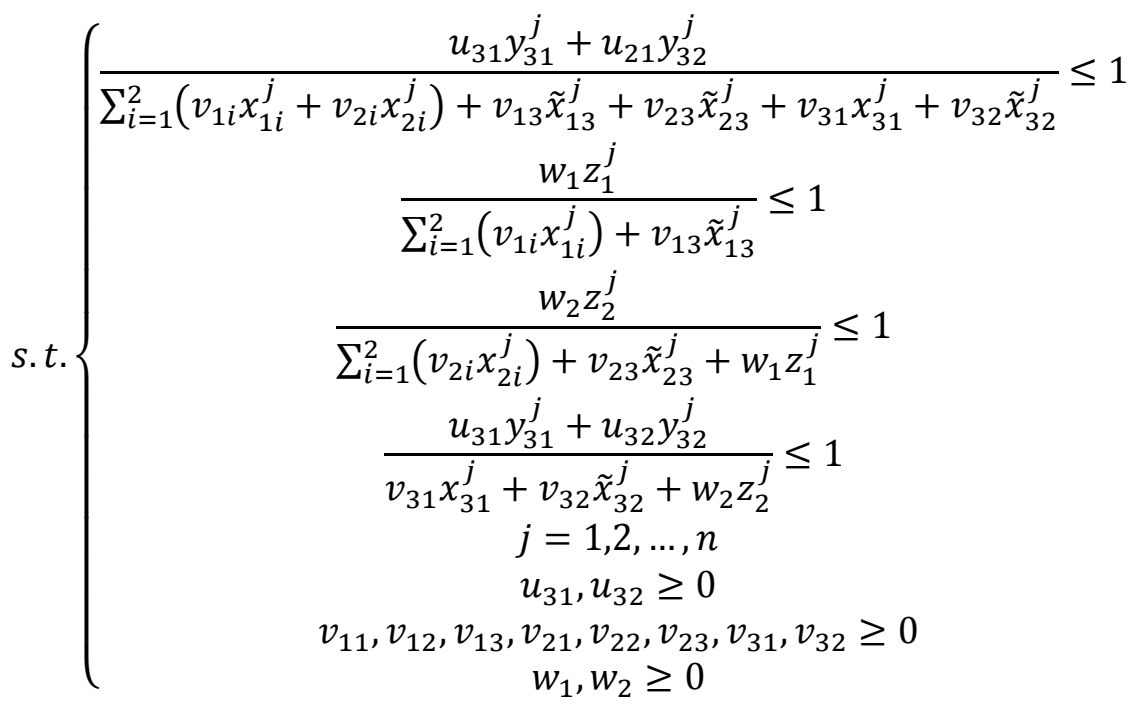


where $x_{h i}^{j}, i=1,2,3$ denotes the $i$ th input, $y_{h r}^{j}, r=1,2$ the $r$ th output, and $z_{f}^{j}, f=1,2$ of the $f$ th intermediary input/output of $j$ th DMU, $j=1, \ldots n$ for the $h$ th sub-process, $h=1,2,3$. The linear equivalent of model (1) (Charnes and Cooper 1962) is presented in model (2):

$E_{k}=\operatorname{Max} u_{31} y_{31}^{k}+u_{32} y_{32}^{k}$

$$
\text { s.t. }\left\{\begin{array}{c}
\sum_{i=1}^{2}\left(v_{1 i} x_{1 i}^{k}+v_{2 i} x_{2 i}^{k}\right)+v_{13} \tilde{x}_{13}^{k}+v_{23} \tilde{x}_{23}^{k}+v_{31} x_{31}^{k}+v_{32} \tilde{x}_{32}^{k}=1 \\
u_{31} y_{31}^{j}+u_{21} y_{32}^{j}-\left(\sum_{i=1}^{2}\left(v_{1 i} x_{1 i}^{j}+v_{2 i} x_{2 i}^{j}\right)+v_{13} \tilde{x}_{13}^{j}+v_{23} \tilde{x}_{23}^{j}+v_{31} x_{31}^{j}+v_{32} \tilde{x}_{32}^{j}\right) \leq 0 \\
w_{1} z_{1}^{j}-\left(\sum_{i=1}^{2}\left(v_{1 i} x_{1 i}^{j}\right)+v_{13} \tilde{x}_{13}^{j}\right) \leq 0 \\
w_{2} z_{2}^{j}-\left(\sum_{i=1}^{2}\left(v_{2 i} x_{2 i}^{j}\right)+v_{23} \tilde{x}_{23}^{j}+w_{1} z_{1}^{j}\right) \leq 0 \\
u_{31} y_{31}^{j}+u_{32} y_{32}^{j}-\left(v_{31} x_{31}^{j}+v_{32} \tilde{x}_{32}^{j}+w_{2} z_{2}^{j}\right) \leq 0 \\
j=1,2, \ldots, n \\
u_{31}, u_{32} \geq 0 \\
v_{21}, v_{22}, v_{23}, v_{31}, v_{32} \geq 0 \\
w_{1}, w_{2} \geq 0
\end{array}\right.
$$

Once the optimal values of multipliers $u_{31}^{*}, u_{32}^{*}, v_{11}^{*}, v_{12}^{*}, \ldots, v_{32}^{*}$, and $w_{1}^{*}, w_{2}^{*}$ are obtained using model (2), the overall network efficiency and efficiency of sub-processes are calculated using equations (3a-3d):

$$
\begin{aligned}
& E_{k}=\frac{u_{31}^{*} y_{31}^{k}+u_{32}^{*} y_{32}^{k}}{\sum_{i=1}^{2}\left(v_{1 i}^{*} x_{1 i}^{k}+v_{2 i}^{*} x_{2 i}^{k}\right)+v_{13}^{*} \tilde{x}_{13}^{k}+v_{23}^{*} \tilde{x}_{23}^{k}+v_{31}^{*} x_{31}^{k}+v_{32}^{*} \tilde{x}_{32}^{k}} \\
& E_{k}^{1}=\frac{w_{1}^{*} z_{1}^{k}}{\sum_{i=1}^{2}\left(v_{1 i}^{*} x_{1 i}^{k}\right)+v_{13}^{*} \tilde{x}_{13}^{k}} \\
& E_{k}^{2}=\frac{w_{2}^{*} z_{2}^{k}}{\sum_{i=1}^{2}\left(v_{2 i}^{*} x_{2 i}^{k}\right)+v_{23}^{*} \tilde{x}_{23}^{k}+w_{1}^{*} z_{1}^{k}} \\
& E_{k}^{3}=\frac{u_{31}^{*} y_{31}^{k}+u_{32}^{*} y_{32}^{k}}{v_{31}^{*} x_{31}^{k}+v_{32}^{*} \tilde{x}_{32}^{k}+w_{2}^{*} z_{2}^{k}}
\end{aligned}
$$

\subsection{Application of Fuzzy Sets Theory to the Three-stage Network DEA Model}

Given that QoR inputs (i.e., $\tilde{\mathrm{x}}_{13}, \widetilde{\mathrm{x}}_{23}, \tilde{\mathrm{x}}_{32}$ ) in the proposed model (see Figure 1) are uncertain and are related to the behavioral traits of decision makers, they are evaluated by linguistic 
variables. Sample selection and data gathering procedures are discussed in detail in subsequent sections. Linguistic variables, however, are associated with a certain measure of ambiguity (Zadeh 1975); in the case of the corporate bond network this is reflected within the expert valuations of the identified behavioral factors. Thus, fuzzy sets theory (Zadeh 1965; Bellman and Zadeh 1970) was applied to quantify these variables.

Using the $\alpha$-cut method, we computed the upper and lower limits of the $\alpha$-cuts of the system efficiency according to the model proposed by Kao and Liu (2011). Subsequently, we obtained the bounds of each process, considering the limits of system efficiency. This paper uses triangular fuzzy numbers (TFN) to quantify linguistic evaluations of experts on behavioral factors. TFNs are widely used due to their simplicity and solid theoretical basis (Pedrycz 1994). A TFN can be shown as a triple $\left(a_{1}, a_{2}, a_{3}\right)$, where $a_{1}, a_{2}$, and $a_{3}$ are real numbers and $a_{1} \leq$ $a_{2} \leq a_{3}$. The membership function of $\left(a_{1}, a_{2}, a_{3}\right)$ :

$$
\left\{\begin{array}{c}
0, \quad x \leq a_{1} \\
\frac{x-a_{1}}{a_{2}-a_{1}}, a_{1} \leq x \leq a_{2} \\
\frac{a_{3}-x}{a_{3}-a_{2}}, a_{2} \leq x \leq a_{3} \\
0, \quad x \geq a_{3}
\end{array}\right.
$$

Using (4), the fuzzy variables (i.e., $\tilde{x}_{13}, \tilde{x}_{23}, \tilde{x}_{32}$ ) are specified in the form of fuzzy numbers in (5a)-(5c). Therefore, model (2) becomes a fuzzy DEA model. As Hatami-Marbini et al. (2011) argued in their taxonomy of fuzzy DEA, the class of $\alpha$-level approaches is the most popular fuzzy DEA model. In this paper, we apply a similar model based on $\alpha$-level sets to solve the fuzzy network DEA model (2). An $\alpha$-level set is a crisp set of objects with its membership degree in fuzzy set being greater than or equal to $\alpha$. For a TFN $\left(a_{1}, a_{2}, a_{3}\right)$, its $\alpha$ level set at a given value of $\alpha$ could be specified by a closed interval of $\left[a_{\alpha}^{L}, a_{\alpha}^{U}\right]=$ $\left[(1-\alpha) a_{1}+\alpha a_{2}, \alpha a_{2}+(1-\alpha) a_{3}\right]$. Consequently, fuzzy variables (i.e., $\left.\tilde{x}_{13}, \tilde{x}_{23}, \tilde{x}_{32}\right)$ in 
model (2) are rearranged as TFNs $\left(x_{13}^{1}, x_{13}^{2}, x_{13}^{3}\right),\left(x_{23}^{1}, x_{23}^{2}, x_{23}^{3}\right),\left(x_{32}^{1}, x_{32}^{2}, x_{32}^{3}\right)$. The corresponding $\alpha$-level of this set of TFNs for a specific value of $\alpha$ is as follows:

$$
\begin{aligned}
& {\left[\left(x_{13}\right)_{\alpha}^{L},\left(x_{13}\right)_{\alpha}^{U}\right]=\left[(1-\alpha) x_{13}^{1}+\alpha x_{13}^{2}, \alpha x_{13}^{2}+(1-\alpha) x_{13}^{3}\right]} \\
& {\left[\left(x_{23}\right)_{\alpha}^{L},\left(x_{23}\right)_{\alpha}^{U}\right]=\left[(1-\alpha) x_{23}^{1}+\alpha x_{23}^{2}, \alpha x_{23}^{2}+(1-\alpha) x_{23}^{3}\right]} \\
& {\left[\left(x_{32}\right)_{\alpha}^{L},\left(x_{32}\right)_{\alpha}^{U}\right]=\left[(1-\alpha) x_{32}^{1}+\alpha x_{32}^{2}, \alpha x_{32}^{2}+(1-\alpha) x_{32}^{3}\right]}
\end{aligned}
$$

Considering (5a)-(5c), the upper bound efficiency of $\mathrm{DMU}_{\mathrm{k}}$ at a specific $\alpha$-level is determined by solving the following:

$$
\left(E_{k}\right)_{a}^{U}=\operatorname{Max}_{31} y_{31}^{k}+u_{32} y_{32}^{k}
$$

$$
\text { s.t. }\left\{\begin{array}{c}
\sum_{i=1}^{2}\left(v_{1 i} x_{1 i}^{k}+v_{2 i} x_{2 i}^{k}\right)+v_{13}\left(x_{13}^{k}\right)_{\alpha}^{L}+v_{23}\left(x_{23}^{k}\right)_{\alpha}^{L}+v_{31} x_{31}^{k}+v_{32}\left(x_{32}^{k}\right)_{\alpha}^{L}=1 \\
u_{31} y_{31}^{k}+u_{21} y_{32}^{k}-\left(\sum_{i=1}^{2}\left(v_{1 i} x_{1 i}^{k}+v_{2 i} x_{2 i}^{k}\right)+v_{13}\left(x_{13}^{k}\right)_{\alpha}^{L}+v_{23}\left(x_{23}^{k}\right)_{\alpha}^{L}+v_{31} x_{31}^{k}+v_{32}\left(x_{32}^{k}\right)_{\alpha}^{L}\right) \leq 0 \\
u_{31} y_{31}^{j}+u_{21} y_{32}^{j}-\left(\sum_{i=1}^{2}\left(v_{1 i} x_{1 i}^{j}+v_{2 i} x_{2 i}^{j}\right)+v_{13}\left(x_{13}^{j}\right)_{\alpha}^{U}+v_{23}\left(x_{23}^{j}\right)_{\alpha}^{U}+v_{31} x_{31}^{j}+v_{32}\left(x_{32}^{j}\right)_{\alpha}^{U}\right) \leq 0, j \neq k \\
w_{1} z_{1}^{k}-\left(\sum_{i=1}^{2}\left(v_{1 i} x_{1 i}^{k}\right)+v_{13}\left(x_{13}^{k}\right)_{\alpha}^{L}\right) \leq 0 \\
w_{1} z_{1}^{j}-\left(\sum_{i=1}^{2}\left(v_{1 i} x_{1 i}^{j}\right)+v_{13}\left(x_{13}^{j}\right)_{\alpha}^{U}\right) \leq 0, j \neq k \\
w_{2} z_{2}^{k}-\left(\sum_{i=1}^{2}\left(v_{2 i} x_{2 i}^{k}\right)+v_{23}\left(x_{23}^{k}\right)_{\alpha}^{L}+w_{1} z_{1}^{k}\right) \leq 0 \\
w_{2} z_{2}^{j}-\left(\sum_{i=1}^{2}\left(v_{2 i} x_{2 i}^{j}\right)+v_{23}\left(x_{23}^{j}\right)_{\alpha}^{U}+w_{1} z_{1}^{j}\right) \leq 0, j \neq k \\
u_{31} y_{31}^{k}+u_{32} y_{32}^{k}-\left(v_{31} x_{31}^{k}+v_{32}\left(x_{32}^{k}\right)_{\alpha}^{L}+w_{2} z_{2}^{k}\right) \leq 0 \\
u_{31} y_{31}^{j}+u_{32} y_{32}^{j}-\left(v_{31} x_{31}^{j}+v_{32}\left(x_{32}^{k}\right)_{\alpha}^{U}+w_{2} z_{2}^{j}\right) \leq 0 \\
j=1,2, \ldots, n \\
u_{31}, u_{32} \geq 0 \\
w_{1}, w_{2} \geq 0 \\
v_{11}, v_{12}, v_{13}, v_{21}, v_{22}, v_{23}, v_{31}, v_{32} \geq 0 \\
w_{3} \geq 0
\end{array}\right.
$$

Similar to model (2), and after calculating optimal values for $u_{31}^{*}, u_{32}^{*}, v_{11}^{*}, v_{12}^{*}, \ldots, v_{32}^{*}$, and $w_{1}^{*}, w_{2}^{*}$, the upper bound overall $\alpha$-cut efficiency score of the network and efficiency of its sub-processes for $\mathrm{DMU}_{\mathrm{k}}$ are obtained using the following equations (7a)-(7d): 


$$
\begin{aligned}
& \left(E_{k}\right)_{\alpha}^{U}=\frac{u_{31}^{*} y_{31}^{k}+u_{32}^{*} y_{32}^{k}}{\sum_{i=1}^{2}\left(v_{1 i}^{*} x_{1 i}^{k}+v_{2 i}^{*} x_{2 i}^{k}\right)+v_{13}^{*}\left(x_{13}^{k}\right)_{\alpha}^{L}+v_{23}^{*}\left(x_{23}^{k}\right)_{\alpha}^{L}+v_{31}^{*} x_{31}^{k}+v_{32}^{*}\left(x_{32}^{k}\right)_{\alpha}^{L}} \\
& \left(E_{k}^{1}\right)_{\alpha}^{U}=\frac{w_{1}^{*} z_{1}^{k}}{\sum_{i=1}^{2}\left(v_{1 i}^{*} x_{1 i}^{k}\right)+v_{13}^{*}\left(x_{13}^{k}\right)_{\alpha}^{L}} \\
& \left(E_{k}^{2}\right)_{\alpha}^{U}=\frac{w_{2}^{*} z_{2}^{k}}{\sum_{i=1}^{2}\left(v_{2 i}^{*} x_{2 i}^{k}\right)+v_{23}^{*}\left(x_{23}^{k}\right)_{\alpha}^{L}+w_{1}^{*} z_{1}^{k}} \\
& \left(E_{k}^{3}\right)_{\alpha}^{U}=\frac{u_{31}^{*} y_{31}^{k}+u_{32}^{*} y_{32}^{k}}{v_{31}^{*} x_{31}^{k}+v_{32}^{*}\left(x_{23}^{k}\right)_{\alpha}^{L}+w_{2}^{*} z_{2}^{k}}
\end{aligned}
$$

The upper bound model presented in model (6) is obtained by setting fuzzy input variables for $\mathrm{DMU}_{\mathrm{k}}$ at their lower bounds, while other DMUs take the upper bound values of these variables. Kao and Liu (2011) and Kao and Liu (2014) show that the lower bound efficiency of the overall network and its sub-processes is calculated using the dual model of (2). According to the duality theorem (Dantzig 1963), the objective functions of the primal and dual models of the network in Figure 1 yield the same value. Using the dual of model (2), the lower bound efficiency of the overall network at a certain $\alpha$-level for $\mathrm{DMU}_{\mathrm{k}}$ is as below:

$$
\left(E_{0}\right)_{a}^{L}=\operatorname{Min} \varepsilon\left(\left(\sum_{i=1}^{2} s_{1 i}^{v}\right)+s_{13}^{v}+\left(\sum_{i=1}^{2} s_{2 i}^{v}\right)+s_{23}^{v}+s_{31}^{v}+s_{32}^{v}+s_{1}^{w}+s_{2}^{w}+s_{31}^{u}+s_{32}^{u}\right)
$$




$$
\begin{aligned}
& \left\{\begin{array}{c}
\theta x_{1 i}^{k}-\sum_{j=1}^{n} \alpha_{j} x_{1 i}^{j}-\sum_{j=1}^{n} \beta_{j} x_{1 i}^{j}-s_{1 i}^{v}=0, i=1,2 \\
\theta\left(x_{13}^{k}\right)_{\alpha}^{U}-\left[\alpha_{k}\left(x_{13}^{k}\right)_{\alpha}^{U}-\sum_{j=1, j \neq k}^{n} \alpha_{j}\left(x_{13}^{j}\right)_{\alpha}^{L}\right]-\left[\beta_{k}\left(x_{13}^{k}\right)_{\alpha}^{U}-\sum_{j=1, j \neq k}^{n} \beta_{j}\left(x_{13}^{j}\right)_{\alpha}^{L}\right]-s_{13}^{v}=0
\end{array}\right. \\
& \theta x_{2 i}^{k}-\sum_{j=1}^{n} \alpha_{j} x_{2 i}^{j}-\sum_{j=1}^{n} \beta_{j} x_{2 i}^{j}-s_{2 i}^{v}=0, i=1,2 \\
& \theta\left(x_{23}^{k}\right)_{\alpha}^{U}-\left[\alpha_{k}\left(x_{23}^{k}\right)_{\alpha}^{U}-\sum_{j=1, j \neq k}^{n} \alpha_{j}\left(x_{23}^{j}\right)_{\alpha}^{L}\right]-\left[\beta_{k}\left(x_{23}^{k}\right)_{\alpha}^{U}-\sum_{j=1, j \neq k}^{n} \beta_{j}\left(x_{23}^{j}\right)_{\alpha}^{L}\right]-s_{23}^{v}=0 \\
& \theta x_{31}^{k}-\sum_{j=1}^{n} \alpha_{j} x_{31}^{j}-\sum_{j=1}^{n} \beta_{j} x_{31}^{j}-s_{31}^{v}=0, i=1,2 \\
& \text { s.t. }\left\{\theta\left(x_{32}^{k}\right)_{\alpha}^{U}-\left[\alpha_{k}\left(x_{32}^{k}\right)_{\alpha}^{U}-\sum_{j=1, j \neq k}^{n} \alpha_{j}\left(x_{32}^{j}\right)_{\alpha}^{L}\right]-\left[\beta_{k}\left(x_{32}^{k}\right)_{\alpha}^{U}-\sum_{j=1, j \neq k}^{n} \beta_{j}\left(x_{32}^{j}\right)_{\alpha}^{L}\right]-s_{32}^{v}=0\right. \\
& \sum_{j=1}^{n} \beta_{j} z_{1}^{j}-\sum_{j=1}^{n} \gamma_{j} z_{1}^{j}-s_{1}^{w}=0 \\
& \sum_{j=1}^{n} \gamma_{j} z_{2}^{j}-\sum_{j=1}^{n} \delta_{j} z_{2}^{j}-s_{2}^{w}=0 \\
& \sum_{j=1}^{n} \alpha_{j} y_{31}^{j}-\sum_{j=1}^{n} \gamma_{j} y_{31}^{j}-s_{31}^{u}=y_{31}^{k} \\
& \sum_{j=1}^{n} \alpha_{j} y_{32}^{j}-\sum_{j=1}^{n} \gamma_{j} y_{32}^{j}-s_{32}^{u}=y_{32}^{k} \\
& \alpha_{j}, \beta_{j}, \gamma_{j}, \delta_{j}, s_{1 i}^{v}, s_{13}^{v}, s_{2 i}^{v}, s_{23}^{v}, s_{31}^{v}, s_{32}^{v}, s_{1}^{w}, s_{2}^{w}, s_{31}^{u}, s_{32}^{u} \geq 0 \\
& i=1,2 \\
& j=1,2, \ldots, n
\end{aligned}
$$

Once the optimal values $s_{31}^{u *}, s_{32}^{u *}, s_{11}^{v *}, s_{12}^{v *}, \ldots, s_{1}^{w *}, s_{2}^{w *}$ are determined and replaced by $u_{31}^{*}, u_{32}^{*}$, $v_{11}^{*}, v_{12}^{*}, \ldots, w_{1}^{*}, w_{2}^{*}$, the lower bound overall $\alpha$-cut efficiency score of the network and efficiency of its sub-processes for $\mathrm{DMU}_{\mathrm{k}}$ are obtained using the following equations (9a)-(9d):

$$
\begin{aligned}
\left(E_{k}\right)_{\alpha}^{L} & =\frac{u_{31}^{*} y_{31}^{k}+u_{32}^{*} y_{32}^{k}}{\sum_{i=1}^{2}\left(v_{1 i}^{*} x_{1 i}^{k}+v_{2 i}^{*} x_{2 i}^{k}\right)+v_{13}^{*}\left(x_{13}^{k}\right)_{\alpha}^{U}+v_{23}^{*}\left(x_{23}^{k}\right)_{\alpha}^{U}+v_{31}^{*} x_{31}^{k}+v_{32}^{*}\left(x_{32}^{k}\right)_{\alpha}^{U}} \\
\left(E_{k}^{1}\right)_{\alpha}^{L} & =\frac{w_{1}^{*} z_{1}^{k}}{\sum_{i=1}^{2}\left(v_{1 i}^{*} x_{1 i}^{k}\right)+v_{13}^{*}\left(x_{13}^{k}\right)_{\alpha}^{U}}
\end{aligned}
$$




$$
\begin{aligned}
& \left(E_{k}^{2}\right)_{\alpha}^{L}=\frac{w_{2}^{*} z_{2}^{k}}{\sum_{i=1}^{2}\left(v_{2 i}^{*} x_{2 i}^{k}\right)+v_{23}^{*}\left(x_{23}^{k}\right)_{\alpha}^{U}+w_{1}^{*} z_{1}^{k}} \\
& \left(E_{k}^{3}\right)_{\alpha}^{L}=\frac{u_{31}^{*} y_{31}^{k}+u_{32}^{*} y_{32}^{k}}{v_{31}^{*} x_{31}^{k}+v_{32}^{*}\left(x_{23}^{k}\right)_{\alpha}^{U}+w_{2}^{*} z_{2}^{k}}
\end{aligned}
$$

To obtain the fuzzy efficiency of $\mathrm{DMU}_{\mathrm{k}}$, the lower bound and upper bound efficiency models are solved for $\alpha=0$ and $\alpha=1$. The triangular fuzzy efficiency of $D M U_{k}$ is determined as $\widetilde{\mathrm{E}_{0}}=\left[\left(\mathrm{E}_{0}\right)_{0}^{\mathrm{L}},\left(\mathrm{E}_{0}\right)_{1},\left(\mathrm{E}_{0}\right)_{0}^{\mathrm{U}}\right]$ considering $\left(\mathrm{E}_{0}\right)_{1}=\left(\mathrm{E}_{0}\right)_{1}^{\mathrm{L}}=\left(\mathrm{E}_{0}\right)_{1}^{\mathrm{U}}$ (see Table 2). The values of $\widetilde{E_{j}}, j=1,2, \ldots, n$ are the triangular fuzzy efficiencies that will be used to meet the model's objectives. The above-mentioned $\alpha$-level-based approach could be extended to different membership functions by using their corresponding $\alpha$-levels in the lower-bound and upperbound models.

\subsection{Case Example}

We investigated corporate bond networks in Iran, including several commercial banks, their corporate banks, external investment banks, their corporate clients, and investors. Iran's emerging market, its significant potential for investments, and simultaneous lack of sufficient scientific analyzes of its economic and financial environment for the past 36 years have made it an intriguing area of exploration by foreign investors (Wright and Thornton 2015). Additionally, the fixed $20 \%$ coupon on investments in the corporate and government bonds has raised global interest in Iran's bond market (Ramezanpour 2015; Rao 2014). Since its inauguration in the 1990s and following the same global standards, issuing and underwriting bonds in Iran has created an annual turnover of millions and in some cases billions of US dollars (Ramezanpour 2015). Government and corporate bonds were previously issued by independent investment banks, but after corporate banking was introduced into Iran's financial market in 2007, both investment banks and corporate banks have been competing to gain a larger share 
of the corporate bond market. According to our model in Figure 1, each DMU consists of a specific commercial bank, its corporate bank or an investment bank (underwriter), a corporate client (issuer), and investors who purchase the bonds. Including four commercial banks (Eghtesad Novin (EN) Bank, Mellat Bank, Melli Bank, and Saman Bank), their corporate banking divisions and four investment banks (Amin, Novin, Omid, Sepehr) resulted in 20 corporate bond networks as independent DMUs (see Table 2). In all these DMUs, members have collaborated with each other in at least one relevant bond issuing and underwriting project. The names of corporate clients and investors are not included here because of the banks' confidentiality policies.

\subsection{Data Collection and Application}

Following the guidelines of Yin (2009), we examined relevant archival data of nominated banks and investment banks and official auditing reports issued by the commercial banks and Central Bank of Iran to obtain the required data for non-fuzzy inputs, outputs, and intermediary inputs/outputs (see Figure 1). Descriptive statistics of the input and output data are available upon request. Following the suggestions by Fawcett et al. (2011), we then conducted semistructured interviews with representatives from banks, investment banks, corporate clients, and investors, in order to determine the values for fuzzy inputs (i.e., quality of relations between members of the corporate bond network) within the model.

We used Critical Incident Technique (CIT) during the interviews to gain a better insight into the underlying behavioral factors that adversely affect efficiency in corporate bond network. CIT is defined as "a qualitative interview procedure, which facilitates the investigation of significant occurrences (events, incidents, processes, or issues) identified by the respondent, the way they are managed, and the outcomes in terms of perceived effects" 
(Chell 1998). The application of CIT to analyze human behavior, especially in service contexts such as the banking industry, has several benefits (Gremler 2004):

i. it provides a rich source of data by guiding respondents toward giving a range of responses based on first-hand experiences and through storytelling (Gabbott and Hogg 1996),

ii. it represents what respondents actually think, thus avoiding any preconceptions or hasty judgments about how respondents perceive incidents to be important (Chell 1998; Stauss 1993),

iii. it provides rich and concrete information that is applicable by managers and decision makers to improve real-world practices ( $\underline{\text { Stauss 1993) }}$.

In addition to the above, CIT is an inductive method and so is most helpful when little is known about the topic under investigation (Gremler 2004), such as the study of behavioral factors affecting efficiency in the corporate bond network.

We conducted 22 interviews with representatives from banks, investment banks, corporate customers, and investors between December 2013 and March 2014. The interviews were conducted to the point where redundancies were occurring and no new sets of incidents were achieved (Flanagan 1954). Respondent profiles and a sample of interview protocols are presented in Appendix A and Appendix B, respectively.

Interviewing time ranged between 30 minutes and two hours. Multiple investigators conducted the interviews and analyzed the outcomes to ensure validity of the results (Eisenhardt 1989; Benbasat et al. 1987). Sampling process followed the theoretical sampling principles of Glaser and Strauss (1967), whereby the relationships between concepts and dimensions are revealed in the first few interviews. The sample comprised mostly middle/top managers of the banks, corporate banks, investment banks, and the corporate clients as the main decision makers of their organization, along with groups of individual customers. The 
interview protocol was initially developed by the authors and was reviewed by three researchers familiar with qualitative research and behavioral sciences. The semi-structured interview protocol using CIT (Flanagan 1954) allowed for open discussions unconstrained by preconceptions, which made it adjustable to the respondents' feedback (Gioia et al. 2013).

The interview protocol consisted of four main parts (Appendix A). Part (A) comprised general questions about interviewees' responsibilities that were relevant to the processes in the corporate bond network. Additionally, respondents were asked to remember their negative experiences dealing with other members of the corporate bond network and the likely behavioral factors behind them. Based on respondents' experiences, in Part (B) we asked them to analyze and prioritize the impact of those experiences on the quality of relations with the other member(s) with whom they were directly interacting, and the likelihood of respondents continuing to work with those members in the future. In parts (C) and (D) we asked respondents if they knew about any possible links relevant to the quality of relations between other members of the network and their impact on their negative experiences in the network.

\subsection{Data Interpretation}

Data analysis incorporated both content analytic method (Kassarjian 1977) and an interpretive approach (Holbrook and O'Shaughnessy 1988). Because the sample was small, transcripts were analyzed manually, with two co-authors carrying out the coding. Critical incidents were chosen from the content, based on relevance to the topic of study. Considering we were interested in the main behavioral factors that could affect efficiency at each stage in the corporate bond network, we reported on all identified behavioral factors relevant to bond issuing, underwriting, and selling processes as critical incidents, ordered by frequency of mention by respondents. Inter-rater reliability of $86 \%$ was based on the number of agreed coding decisions to the total number of decisions (Kassarjian 1977). Any disagreements about the coding were resolved 
between the co-authors before reporting the results. The most important critical incidents for each stage according to their frequency (above 10\%) are reported in Table 1. We also adopted an interpretive approach (Holbrook and O'Shaughnessy 1988), delineating the possible causes of the behavioral factors identified, since "employing an interpretive approach may help researchers better understand emotions in the context of the critical incidents" (Gremler 2004). Thus, borrowing from the literature on behavioral operations and supply chain management as well as how respondents felt about different situations categorized as critical incidents, we also reported on the possible causes of the main behavioral factors in Table 1. We interpreted possible causes of the incidents as either independent or linked to other incidents identified in the interviews (Edvardsson and Strandvik 2000). For instance, "mistrust", mentioned by most respondents as the overriding behavioral factor affecting the quality of relations in all three stages, could stem from either anchoring on past negative experiences, as interpreted by the authors, or it could result from the opportunistic behavior by the services supplier (i.e., investment bank, corporate bank, or bank), as mentioned by respondents. The interpretations of the critical incidents by the authors were examined by four colleagues who were experts in behavioral sciences or service supply chains.

Insert Table 1 about here

In addition to the behavioral factors discussed in the literature review section above, Table 1 includes other behavioral regularities believed to cause inefficiencies in corporate bond service networks. For instance, "overestimating financial stability of issuer" in Stage I is interpreted to be due to "information avoidance" of bank decision makers, which prevents them making unbiased judgments of their corporate customers' financial stability. Information avoidance is the tendency to overlook information that causes discomfort and, in the context of supply chain management, it could result in several biased decisions by managers regarding 
their suppliers, customers, or investments in different projects (Gino and Pisano 2008). Other authors provide a description of the behavioral factors, their causes mentioned in Table 1, and their application in the context of operations and supply chain management (Gino and Pisano 2008; Bendoly et al. 2010). Other possible causes of this overestimation could be banks' "overconfidence" in their accurate evaluation of issuers' financial stability, or continuing to work with financially unstable issuers based merely on the costs already incurred and which cannot be recovered without considering future losses (i.e., "sunk costs fallacy"). Knowing details of the behavioral factors could contribute to more effective post hoc analyses of the sources of inefficiencies obtained from the DEA model. We further elaborate on this later in the results and discussion section.

Once respondents had identified all the behavioral factors, they were asked to prioritize the quality of their relations with other members in the corporate bond network. Linguistic terms were used in the form of five-point Likert scale, with each scale being transformed into a TFN (i.e., "very low" $(1,1,3)$, "low"(1,3,5), "neutral" $(3,5,7)$, "high" $(5,7,9)$, and "very high" $(7,9,9))$. The average scores obtained by the interviews specific to each stage for each DMU were used in the proposed fuzzy network DEA model. For instance, if investors evaluated quality of their relations with Mellat Bank's officers high on average and they had not noticed much misbehaviors the TFN $(5,7,9)$ was replaced as the value of $\tilde{x}_{32}$ for all the corporate bonds with Mellat Bank in them. The DMUs presented in Table 2, despite having some similarities, differ in having either investment banks or corporate banks as their underwriters, and this distinction is made in Table 2 by reporting the efficiency scores of those DMUs separately.

\section{Results and discussion}

Table 2 illustrates the numerical outcomes of the study using the proposed fuzzy network DEA model, presenting the overall efficiency scores and the efficiency scores in each of the 
three stages. On average, corporate bond networks with corporate banks as their underwriters showed marginally better overall efficiency. However, comparison of stagewise efficiency scores reveal that corporate bond networks with investment banks as underwriters were performing significantly better in Stage I $(p-$ value $=0.00)$, indicating to more efficienct underwriter-issuer operations in this network. Nevertheless, in Stage II corporate bank-bank operations showed higher levels of efficiency compared to investment bank-bank operations $(p-$ value $=0.01)$. No significant difference is observed in performance of the two networks in Stage III.

Individual rankings of the DMUs showed that while most of the corporate bond networks showed higher overall efficiency scores with corporate banks as underwriters, Eghtesad Novin Bank was more efficienct when collaborating with investment banks, rather than its own corporate bank, for bond issuance and underwriting. In fact, the corporate bond network of Eghtesad Novin- Novin Investment Bank has the highest efficiency score among all other DMUs. Another observation from Table 2 and Figure 3 is a surprisingly lower efficiency in issuer-corporate bank operations compared to other stages in these networks. This could have serious implictaions for banks to increase supervision and control over how corporate banks are dealing with corporate customers for bond underwriting and issuance purposes. We will delve deeper into the specific sources of inefficiencies for all networks in the next section.

Insert Table 2 about here

Figures 2 and 3 illustrate the comparisons between efficiency scores in different stages for the corporate bond network with investment banks or corporate banks as underwriters. In both figures, the efficiency level of the network in Stage III is higher than in the other two stages. However, the patterns of overall efficiency scores and Stage II efficiency scores are most similar. This could be an indicator that the performance of bank and underwriter in Stage II is 
determinant of the overall efficiency of the corporate bond network. Thus, this could be interpreted as banks paying specific attention to bank-underwriter operations in the corporate bonds network to ensure an acceptable overall efficiency in this network.

In order to determine with more certainty which sets of inputs or outputs in the corporate bond network model have the highest levels of impact on the overall efficiency, we conducted several tests of sensitivity and a robustness check of the efficiency scores to variations in inputs and outputs.

Insert Figure 2 and Figure 3 about here

Initially, we tested the sensitivity of the results to the sample size. Overall, the model in Figure 1 had twelve inputs, outputs, and intermediary inputs/outputs. As a general heuristic, this requires at least $36(12 * 3)$ DMUs to ensure an acceptable level of discrimination. Kao (2009), however, explains that in network DEA models the total number of DMUs are multiplied by the number of sub-processes. Considering the total number of 20 DMUs and three sub-processes $(20 * 3>12 * 3)$, we are confident that our sample size was sufficient. Table 3 illustrates potential improvements in efficiency scores by making changes in the inputs and outputs of the corporate bond network model, compared with the benchmark frontier. The results are reported using the full sample and two subsamples that represent networks with either corporate banks or investment banks as their underwriters.

Insert Table 3 about here

As shown in Table 3, most inefficiencies in the first two stages stem mainly from "quality of relations" (QoR) between either underwriter and issuer or bank and underwriter. Further investigation of sources of inefficiencies for QoR revealed that, while in Stage I corporate banks show a poorer quality of relations with issuers, in Stage II investment banks' relations 
with banks has more potential for improvement. Considering a significantly lower level of efficiency in Stage I for the networks with corporate banks as their underwriters (see Figure 3), Table 3 reveals that the overriding priotity for improvement in these networks should be improving the relations between banks and their own corporate banking divisions. Additionally, in Stage III most of the inefficiencies are embedded in QoR and also "proportion of bonds sold to total" (SBT), which calls for the banks' decision makers to pay attention to their relations with their investors, gaining their trust, and using alternative marketing strategies to sell the bonds.

\subsection{Managerial Implications}

The results of this study reveal that managers should pay equal attention to operational and behavioral factors when addressing inefficiencies within supply networks. The sources of inefficiencies in the corporate bond network identified in Table 2 indicate that the quality of bilateral relations should be improved in all three stages. As discussed earlier, we posited several reasons for the poor quality of relations depicted in the three stages of corporate bond networks. Taking this into consideration, we recommend that managers take the following steps to help overcome inefficiencies caused by behavioural issues throughout their supply network.

First, for instance in Stage I, having identified and acknowledged goals by the employees regarding the quality of services they offer to the issuer, managers should implement a control and feedback mechanism to constantly monitor individuals' motivation levels, thereby keeping employees of investment banks or corporate banks motivated enough to provide quality services to issuers. Second, managers should apply control mechanisms and supervision over issuers (especially the investment bank) to preclude them adopting opportunistic behavior. The latter should also be addressed by strengthening trust levels between bank and issuer. Third, 
managers should implement debiasing strategies to reduce the impact of identified behavioral biases (e.g., anchoring, overconfidence, suck costs fallacy) on the quality of decisions made in Stage I by providing warnings and awareness about the decision biases, decomposing complex decision tasks into smaller components, and applying multiple perspectives to view decision

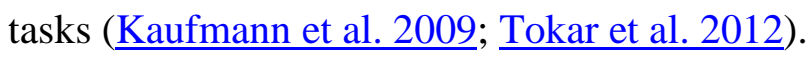

Other debiasing measures to be taken in supply chains can reduce the effects of dynamism in the decision-making context (Haines et al. 2010; Kaufmann et al. 2009). Overall, the extent of dynamism in the environment moderates between rational and comprehensive decision making and decision quality (Hough and White 2003). Reducing dynamism in Stage I and in the corporate bond network in general requires identifying changes in business and updating marketing strategies for the bonds, and applying tools and mechanisms that could detect and address changes in both external and internal operational and behavioral factors affecting efficiency in this network. Furthermore, an unambiguous set of information could help reduce complexities in the decision-making environment, leading to fewer biases in the decisionmaking process (Kaufmann et al. 2009). This could be achieved in the corporate bond network by developing databases that could capture and analyze all information relevant to the operational and behavioral factors identified in this study. In fact, gathering information more frequently and efficiently, especially in dynamic environments such as supply networks, is believed to be critical to engage decision makers in "procedural rationality" as an important decision-making approach (Riedl et al. 2013; Haines et al. 2010).

In Stage II, quality of relations between underwriters and banks was identified as the primary source of inefficiency in the corporate bond network (Table 2). The deteriorating relations in this stage could have adverse consequences on Stage I in terms of opportunistic behavior of the underwriter, as discussed above. To avoid this outcome, the same measures and debiasing strategies discussed for Stage I should be adopted. Additionally, in Stage III, both 
operational and behavioral factors had significant negative effects on the stage-wise and overall efficiency of the network (Table 2). First, the proportion of bonds sold in relation to the total quantity of bonds is contingent upon several behavioral and non-behavioral factors. The nonbehavioral factors are usually context-specific and depend upon the return on investment promised by parallel markets (in case of Iran's market, the real estate industry for instance offers much higher returns on investment than the bonds market) or the quality of bonds and marketing strategies for the bonds to attract investors. Similarly, the overriding behavioral factors affecting investors' decisions to purchase the bonds include, for example, trust between investors and bank and the reputation of corporate customer and bank as issuer and seller of the bonds. Thus, managers should consider that operational inefficiencies identified in the supply networks could stem equally from behavioral and operational factors, or perhaps even more from behavioral factors in some cases.

\section{CONCLUSION}

This study attempted to highlight the role of behavioral factors in analytical models used in the operations and supply chain management domain. By adopting a multi-method approach, we incorporated behavioral misconducts of decision makers in standard DEA models for measuring bank efficiency, and we gathered relevant data on behavioral factors using semistructured interviews and critical incident technique. We developed a fuzzy network DEA model to reveal the sources of inefficiencies in issuer-underwriter, underwriter-bank, and bankinvestor interrelations in the presence of behavioral factors in this network. The results showed marginal differences in the efficiency of the networks with either investment banks or corporate banks as their underwriters. Conducting sensitivity analysis on the inputs and outputs of the model in three stages revealed that behavioral factors in corporate bond networks could significantly affect efficiency scores in the network. 
While we envisioned mainly decision making-related scenarios that could be disrupted by decision makers' bounded rationality, the results from the case analysis showed additional behavioral issues present in the bilateral relations throughout the corporate bond network. From this aspect, a limitation of this study framework was that it adopted a general approach toward all the behavioral issues identified in the DEA modeling of the network. Analyzing specific behavioral factors in supply networks would provide more in-depth knowledge of the root causes of errors in judgment and decision making, although such analyses would be limited in number because of the over-complexity of the behavioral models. A second limitation is that we utlized semi-structured interviews and critical incident techniques to gain insight into the behavioral misconducts within the banking industry, despite some authors arguing that laboratory experiments are preferable (Knemeyer and Naylor 2011) because they control for irrelevant biases that might cause errors in the final results of the analyzes.

We recommend that researchers consider incorporating behavioral factors into their performance and efficiency assessment models of supply networks, in order to improve the application of these models to real-world problems. Moreover, the outcomes of this study suggest that decision makers should be more aware of intangible variables, including those behavioral factors in their interrelations with their counterparts in supply networks in general and in the corporate bond service networks in particular.

\section{ACKNOWLEDGEMENT}

The authors would like to thank Professor Endre Boros, the editor of Annals of Operations Research, and anonymised reviewers for their insightful comments and suggestions. 


\section{References}

Agrawal, V., \& Seshadri, S. (2000). Impact of Uncertainty and Risk Aversion on Price and Order Quantity in the Newsvendor Problem. Manufacturing \& Service Operations Management, 2(4), 410-423, doi:doi:10.1287/msom.2.4.410.12339.

Akther, S., Fukuyama, H., \& Weber, W. L. (2013). Estimating two-stage network Slacksbased inefficiency: An application to Bangladesh banking. Omega, 41(1), 88-96, doi:http://dx.doi.org/10.1016/j.omega.2011.02.009.

Andres, C., Betzer, A., \& Limbach, P. (2014). Underwriter reputation and the quality of certification: Evidence from high-yield bonds. Journal of Banking \& Finance, 40, $97-$ 115, doi:10.1016/j.jbankfin.2013.11.029.

Bandura, A. (1989). Human agency in social cognitive theory. American Psychologist, 44(9), 1175-1184, doi:10.1037/0003-066X.44.9.1175.

Bandura, A. (2001). Social cognitive theory: An agentic perspective. Annual Review of Psychology, 52(1), 1-26, doi:doi:10.1146/annurev.psych.52.1.1.

Bazerman, M., \& Moore, D. A. (2012). Judgment in Managerial Decision Making (8th ed.): Wiley \& Sons.

Bellman, R. E., \& Zadeh, L. A. (1970). Decision-Making in a Fuzzy Environment. Management Science, 17(4), B-141-B-164, doi:doi:10.1287/mnsc.17.4.B141.

Benbasat, I., Goldstein, D. K., \& Mead, M. (1987). The Case Research Strategy in Studies of Information Systems. MIS Quarterly, 11(3), 369-386.

Bendoly, E. (2014). System Dynamics Understanding in Projects: Information Sharing, Psychological Safety, and Performance Effects. [Article]. Production and Operations Management, 23(8), 1352-1369, doi:10.1111/poms.12024.

Bendoly, E., Croson, R., Goncalves, P., \& Schultz, K. (2010). Bodies of Knowledge for Research in Behavioral Operations. Production and Operations Management, 19(4), 434-452, doi:10.1111/j.1937-5956.2009.01108.x.

Bendoly, E., Donohue, K., \& Schultz, K. L. (2006). Behavior in operations management: Assessing recent findings and revisiting old assumptions. Journal of Operations Management, 24(6), 737-752, doi:10.1016/j.jom.2005.10.001.

Bendoly, E., van Wezel, W., \& Bachrach, D. G. (2015). The Handbook of Behavioral Operations Management: Social and Psychological Dynamics in Production and Service Settings. New York, NY: Oxford University Press. 
Boyer, K. K., \& Swink, M. L. (2008). Empirical Elephants - Why multiple methods are essential to quality research in operations and supply chain management. Journal of Operations Management, 26, 337-348.

Carter, C. R., Kaufmann, L., \& Michel, A. (2007). Behavioral supply management: a taxonomy of judgment and decision- making biases. International Journal of Physical Distribution \& Logistics Management, 37(8), 631-669, doi:doi:10.1108/09600030710825694.

Charnes, A., \& Cooper, W. W. (1962). Programming with linear fractional functionals. Naval Research Logistics Quarterly, 9(3-4), 181-186, doi:10.1002/nav.3800090303.

Charnes, A., Cooper, W. W., \& Rhodes, E. (1978). Measuring the efficiency of decision making units. [Article]. European journal of operational research, 2(6), 429-444.

Chell, E. (1998). Critical Incident Technique. Thousand Oaks, CA: Sage.

Chen, C., \& Yan, H. (2011). Network DEA model for supply chain performance evaluation. European Journal of Operational Research, 213(1), 147-155, doi:DOI 10.1016/j.ejor.2011.03.010.

Croson, R., Donohue, K., Katok, E., \& Sterman, J. D. (2014). Order Stability in Supply Chains: Coordination Risk and the Role of Coordination Stock. Production and Operations Management, 23(2), 176-196, doi:10.1111/j.1937-5956.2012.01422.x.

Croson, R., Schultz, K., Siemsen, E., \& Yeo, M. L. (2013). Behavioral operations: The state of the field. Journal of Operations Management, 31(1-2), 1-5, doi:http://dx.doi.org/10.1016/j.jom.2012.12.001.

Dantzig, G. B. (1963). Linear Programming and Extensions. Princeton, NJ: Princeton University Press.

Edvardsson, B., \& Strandvik, T. (2000). Is a critical incident critical for a customer relationship? Managing Service Quality: An International Journal, 10(2), 82-91, doi:doi:10.1108/09604520010318272.

Eisenhardt, K. M. (1989). Building Theories from Case Study Research. Academy of Management Review, 14(4), 532-550, doi:10.5465/amr.1989.4308385.

Emrouznejad, A., Parker, B. R., \& Tavares, G. (2008). Evaluation of research in efficiency and productivity: A survey and analysis of the first 30 years of scholarly literature in DEA. Socio-Economic Planning Sciences, 42(3), 151-157, doi:http://dx.doi.org/10.1016/j.seps.2007.07.002.

Fare, R., \& Grosskopf, S. (2000). Network DEA. Socio-Economic Planning Sciences, 34(1), 35-49, doi:http://dx.doi.org/10.1016/S0038-0121(99)00012-9. 
Fare, R., Grosskopf, S., Lovell, C. K., \& Pasurka, C. (1989). Multilateral productivity comparisons when some outputs are undesirable: A nonparametric approach. The Review of Economics and Statistics, 71(1), 90-98.

Fawcett, S. E., Waller, M. A., \& Bowersox, D. J. (2011). Cinderella in the C-Suite: Conducting Influential Research to Advance the Logistics and Supply Chain Disciplines. Journal of Business Logistics, 32(2), 115-121, doi:10.1111/j.21581592.2011.01010.x.

Fethi, M. D., \& Pasiouras, F. (2010). Assessing bank efficiency and performance with operational research and artificial intelligence techniques: A survey. European Journal of Operational Research, 204(2), 189-198, doi:http://dx.doi.org/10.1016/j.ejor.2009.08.003.

Flanagan, J. C. (1954). The critical incident technique. Psychological Bulletin, 51(4), 327358, doi:10.1037/h0061470.

Friend, S. B., \& Johnson, J. S. (2014). Key account relationships: An exploratory inquiry of customer-based evaluations. Industrial Marketing Management, 43(4), 642-658, doi:http://dx.doi.org/10.1016/j.indmarman.2013.11.009.

Gabbott, M., \& Hogg, G. (1996). The glory of stories: Using critical incidents to understand service evaluation in the primary healthcare context. Journal of Marketing Management, 12(6), 493-503, doi:10.1080/0267257X.1996.9964431.

Gande, A., Puri, M., \& Saunders, A. (1999). Bank entry, competition, and the market for corporate securities underwriting. Journal of Financial Economics, 54(2), 165-195, doi:http://dx.doi.org/10.1016/S0304-405X(99)00035-5.

Giannoccaro, I., \& Ilaria, G. (2013). Behavioral Issues in Operations Management New Trends in Design, Management, and Methodologies / Giannoccaro, Ilaria. S.1.]: S.1. : Springer London.

Gino, F., \& Pisano, G. (2008). Toward a Theory of Behavioral Operations. [Article]. M\&Som-Manufacturing \& Service Operations Management, 10(4), 676-691, doi:10.1287/msom.1070.0205.

Gioia, D. A., Corley, K. G., \& Hamilton, A. L. (2013). Seeking Qualitative Rigor in Inductive Research: Notes on the Gioia Methodology. Organizational Research Methods, 16(1), 15-31, doi:10.1177/1094428112452151.

Glaser, B. G., \& Strauss, A. L. (1967). The Discovery of Grounded Theory: Strategies for Qualitative Research. New York, NY.: Aldine De Gruyter. 
Gremler, D. D. (2004). The Critical Incident Technique in Service Research. Journal of Service Research, 7(1), 65-89, doi:10.1177/1094670504266138.

Haines, R., Hough, J. R., \& Haines, D. (2010). Individual And Environmental Impacts On Supply Chain Inventory Management: An Experimental Investigation Of Information Availability And Procedural Rationality. Journal of Business Logistics, 31(2), 111128, doi:10.1002/j.2158-1592.2010.tb00144.x.

Hämäläinen, R. P., Luoma, J., \& Saarinen, E. (2013). On the importance of behavioral operational research: The case of understanding and communicating about dynamic systems. European Journal of Operational Research, 228(3), 623-634, doi:http://dx.doi.org/10.1016/j.ejor.2013.02.001.

Hatami-Marbini, A., Emrouznejad, A., \& Tavana, M. (2011). A taxonomy and review of the fuzzy data envelopment analysis literature: Two decades in the making. European Journal of Operational Research, 214(3), 457-472, doi:10.1016/j.ejor.2011.02.001.

Holbrook, M. B., \& O'Shaughnessy, J. (1988). On the scientific status of consumer research and the need for an interpretive approach to studying consumption behavior. Journal of Consumer Research, 15(3), 398-402, doi:10.1086/209178.

Hough, J. R., \& White, M. A. (2003). Environmental dynamism and strategic decisionmaking rationality: an examination at the decision level. Strategic Management Journal, 24(5), 481-489, doi:10.1002/smj.303.

Kahneman, D., Knetsch, J. L., \& Thaler, R. H. (1991). Anomalies: The Endowment Effect, Loss Aversion, and Status Quo Bias. The Journal of Economic Perspectives, 5(1), 193-206, doi:10.2307/1942711.

Kao, C. (2009). Efficiency decomposition in network data envelopment analysis: A relational model. European Journal of Operational Research, 192(3), 949-962, doi:http://dx.doi.org/10.1016/j.ejor.2007.10.008.

Kao, C. (2014). Network data envelopment analysias: A review. European Journal of Operational Research, 239(1), 1-16, doi:http://dx.doi.org/10.1016/j.ejor.2014.02.039.

Kao, C., \& Hwang, S.-N. (2008). Efficiency decomposition in two-stage data envelopment analysis: An application to non-life insurance companies in Taiwan. European Journal of Operational Research, 185(1), 418-429, doi:http://dx.doi.org/10.1016/j.ejor.2006.11.041.

Kao, C., \& Hwang, S.-N. (2010). Efficiency measurement for network systems: IT impact on firm performance. Decision Support Systems, 48(3), 437-446, doi:http://dx.doi.org/10.1016/j.dss.2009.06.002. 
Kao, C., \& Liu, S.-T. (2011). Efficiencies of two-stage systems with fuzzy data. Fuzzy Sets and Systems, 176(1), 20-35, doi:http://dx.doi.org/10.1016/j.fss.2011.03.003.

Kao, C., \& Liu, S.-T. (2014). Multi-period efficiency measurement in data envelopment analysis: The case of Taiwanese commercial banks. Omega, 47(0), 90-98, doi:http://dx.doi.org/10.1016/j.omega.2013.09.001.

Kassarjian, H. (1977). Content Analysis in Consumer Research. The Journal of Consumer Research, 4(1), 8-18, doi:citeulike-article-id:707234.

Katsikopoulos, K. V., \& Gigerenzer, G. (2013). Behavioral Operations Management: A Blind Spot and a Research Program. [Article]. Journal of Supply Chain Management, 49(1), 3-7, doi:10.1111/j.1745-493x.2012.03285.x.

Kaufmann, L., Michel, A., \& Carter, C. R. (2009). Debiasing Strategies in Supply Management Decision-Making. Journal of Business Logistics, 30(1), 85-106, doi:10.1002/j.2158-1592.2009.tb00100.x.

Knemeyer, A. M., \& Naylor, R. W. (2011). Using Behavioral Experiments to Expand Our Horizons and Deepen Our Understanding of Logistics and Supply Chain Decision Making. Journal of Business Logistics, 32(4), 296-302, doi:10.1111/j.00000000.2011.01025.x.

Latham, G. P., \& Locke, E. A. (1991). Self-regulation through goal setting. Organizational Behavior and Human Decision Processes, 50(2), 212-247, doi:http://dx.doi.org/10.1016/0749-5978(91)90021-K.

Liang, L., Yang, F., Cook, W. D., \& Zhu, J. (2006). DEA models for supply chain efficiency evaluation. [journal article]. Annals of Operations Research, 145(1), 35-49, doi:10.1007/s10479-006-0026-7.

Liu, J. S., Lu, L. Y. Y., Lu, W.-M., \& Lin, B. J. Y. (2013). A survey of DEA applications. Omega, 41(5), 893-902, doi:10.1016/j.omega.2012.11.004.

Locke, E. A., \& Latham, G. P. (2002). Building a practically useful theory of goal setting and task motivation: A 35-year odyssey. American Psychologist, 57(9), 705-717, doi:10.1037/0003-066X.57.9.705.

Lozano, S. (2015). Slacks-based inefficiency approach for general networks with bad outputs: An application to the banking sector. Omega, In press, doi:http://dx.doi.org/10.1016/j.omega.2015.02.012.

Mathis, J., McAndrews, J., \& Rochet, J.-C. (2009). Rating the raters: Are reputation concerns powerful enough to discipline rating agencies? Journal of Monetary Economics, 56(5), 657-674, doi:http://dx.doi.org/10.1016/j.jmoneco.2009.04.004. 
Matthews, K. (2013). Risk management and managerial efficiency in Chinese banks: A network DEA framework. Omega, 41(2), 207-215, doi:DOI 10.1016/j.omega.2012.06.003.

Mingers, J. (2011). Soft OR comes of age—but not everywhere! Omega, 39(6), 729-741, doi:http://dx.doi.org/10.1016/j.omega.2011.01.005.

Mirhedayatian, S. M., Azadi, M., \& Farzipoor Saen, R. (2014). A novel network data envelopment analysis model for evaluating green supply chain management. International Journal of Production Economics, 147, 544-554, doi:10.1016/j.ijpe.2013.02.009.

Moore, D. A., \& Healy, P. J. (2008). The trouble with overconfidence. Psychological Review, 115(2), 502-517, doi:10.1037/0033-295X.115.2.502.

Moreno, P., \& Lozano, S. (2014). A network DEA assessment of team efficiency in the NBA. Annals of Operations Research, 214(1), 99-124, doi:DOI 10.1007/s10479-012-10749.

Mussweiler, T., \& Strack, F. (2001). The Semantics of Anchoring. Organizational Behavior and Human Decision Processes, 86(2), 234-255, doi:http://dx.doi.org/10.1006/obhd.2001.2954.

Nagarajan, M., \& Shechter, S. (2014). Prospect Theory and the Newsvendor Problem. [Article]. Management Science, 60(4), 1057-1062, doi:10.1287/mnsc.2013.1804.

Narayanan, A., \& Moritz, B. B. (2015). Decision Making and Cognition in Multi-Echelon Supply Chains: An Experimental Study. Production and Operations Management, n/a-n/a, doi:10.1111/poms.12343.

Özer, Ö., \& Zheng, Y. (2012). Behavioral issues in pricing management. In O. Ozer, \& R. Phillips (Eds.), The Oxford Handbook of Pricing Management (pp. 415461). Oxford, UK: Oxford University Press.

Özer, Ö., Zheng, Y. C., \& Ren, Y. F. (2014). Trust, Trustworthiness, and Information Sharing in Supply Chains Bridging China and the United States. [Article]. Management Science, 60(10), 2435-2460, doi:10.1287/mnsc.2014.1905.

Paradi, J. C., \& Zhu, H. (2013). A survey on bank branch efficiency and performance research with data envelopment analysis. Omega, 41(1), 61-79, doi:http://dx.doi.org/10.1016/j.omega.2011.08.010.

Pedrycz, W. (1994). Why triangular membership functions? Fuzzy Sets and Systems, 64(1), 21-30, doi:http://dx.doi.org/10.1016/0165-0114(94)90003-5.

Ramezanpour, M. (2015). Iran's troubled bond market. 
Rao, S. (2014). Iran: a frontier for the future.

Read, D., Jin, Y. H., \& Fawcett, S. E. (2014). Trust in Value Co-Creation Strategies: Moving Toward a Conceptualization We Can Trust. Journal of Business Logistics, 35(1), 9798, doi:10.1111/jbl.12040.

Riedl, D. F., Kaufmann, L., Zimmermann, C., \& Perols, J. L. (2013). Reducing uncertainty in supplier selection decisions: Antecedents and outcomes of procedural rationality. Journal of Operations Management, 31(1-2), 24-36, doi:10.1016/j.jom.2012.10.003.

Sanders, N. R., \& Wagner, S. M. (2011). Multidisciplinary and Multimethod Research for Addressing Contemporary Supply Chain Challenges. Journal of Business Logistics, 32(4), 317-323, doi:10.1111/j.0000-0000.2011.01027.x.

Stauss, B. (1993). Using the Critical Incident Technique in Measuring and Managing Service Quality. In E. E. Scheuing, \& W. F. Christopher (Eds.), The Service Quality Handbook (pp. 408-427). New York: American Management Association.

Su, X. (2008). Bounded Rationality in Newsvendor Models. Manufacturing \& Service Operations Management, 10(4), 566-589, doi:doi:10.1287/msom.1070.0200.

Talluri, S., Kull, T. J., Yildiz, H., \& Yoon, J. (2013). Assessing the Efficiency of Risk Mitigation Strategies in Supply Chains. Journal of Business Logistics, 34(4), 253-269, doi:10.1111/jbl.12025.

Tiwana, A., Wang, J., Keil, M., \& Ahluwalia, P. (2007). The Bounded Rationality Bias in Managerial Valuation of Real Options: Theory and Evidence from IT Projects. Decision Sciences, 38(1), 157-181, doi:10.1111/j.1540-5915.2007.00152.x.

Tokar, T., Aloysius, J. A., \& Waller, M. A. (2012). Supply Chain Inventory Replenishment: The Debiasing Effect of Declarative Knowledge. Decision Sciences, 43(3), 525-546, doi:10.1111/j.1540-5915.2012.00355.x.

Tversky, A., \& Kahneman, D. (1974). Judgment under Uncertainty: Heuristics and Biases. Science, 185(4157), 1124-1131, doi:10.1126/science.185.4157.1124.

Vaz, C. B., Camanho, A. S., \& Guimarães, R. C. (2010). The assessment of retailing efficiency using Network Data Envelopment Analysis. [journal article]. Annals of Operations Research, 173(1), 5-24, doi:10.1007/s10479-008-0397-z.

Villena, V. H., Revilla, E., \& Choi, T. Y. (2011). The dark side of buyer-supplier relationships: A social capital perspective. Journal of Operations Management, 29(6), 561-576, doi:http://dx.doi.org/10.1016/j.jom.2010.09.001. 
Wan, X., \& Evers, P. T. (2011). Supply Chain Networks With Multiple Retailers: A Test of the Emerging Theory on Inventories, Stockouts, and Bullwhips. Journal of Business Logistics, 32(1), 27-39, doi:10.1111/j.2158-1592.2011.01003.x.

Wang, C. X., \& Webster, S. (2009). The loss-averse newsvendor problem. [Article]. OmegaInternational Journal of Management Science, 37(1), 93-105, doi:10.1016/j.omega.2006.08.003.

Wang, K., Huang, W., Wu, J., \& Liu, Y.-N. (2014). Efficiency measures of the Chinese commercial banking system using an additive two-stage DEA. Omega, 44, 5-20, doi:10.1016/j.omega.2013.09.005.

Wang, N. M., Ma, Y. G., He, Z. W., Che, A., Huang, Y. F., \& Xu, J. P. (2014). The impact of consumer price forecasting behaviour on the bullwhip effect. [Article]. International Journal of Production Research, 52(22), 6642-6663, doi:10.1080/00207543.2014.907513.

Wathne, K. H., \& Heide, J. B. (2000). Opportunism in Interfirm Relationships: Forms, Outcomes, and Solutions. Journal of Marketing, 64(4), 36-51, doi:doi:10.1509/jmkg.64.4.36.18070.

Wright, C., \& Thornton, P. (2015). Iran poised to exit 'deep freeze' with bond issues, UK visit.

Wu, D. D., \& Birge, J. R. (2012). Serial Chain Merger Evaluation Model and Application to Mortgage Banking. Decision Sciences, 43(1), 5-36, doi:10.1111/j.15405915.2011.00340.x.

Wu, D. D., \& Olson, D. (2009). Enterprise risk management: a DEA VaR approach in vendor selection. International Journal of Production Research, 48(16), 4919-4932, doi:10.1080/00207540903051684.

Wu, D. Y., \& Chen, K.-Y. (2014). Supply Chain Contract Design: Impact of Bounded Rationality and Individual Heterogeneity. Production and Operations Management, 23(2), 253-268, doi:10.1111/poms.12057.

Yang, F., Wu, D., Liang, L., Bi, G., \& Wu, D. D. (2011). Supply chain DEA: production possibility set and performance evaluation model. [journal article]. Annals of Operations Research, 185(1), 195-211, doi:10.1007/s10479-008-0511-2.

Yasuda, A. (2005). Do bank relationships affect the firm's underwriter choice in the corporate-bond underwriting market? Journal of Finance, 60(3), 1259-1292, doi:10.1111/j.1540-6261.2005.00761.x. 
Yasuda, A. (2007). Bank relationships and underwriter competition: Evidence from Japan. Journal of Financial Economics, 86(2), 369-404, doi:http://dx.doi.org/10.1016/j.jfineco.2006.08.006.

Yin, R. K. (2009). Case study research: Design and methods (Vol. 5). Thousand Oaks, CA: Sage Publications.

Zadeh, L. A. (1965). Fuzzy sets. Information and Control, 8(3), 338-353, doi:http://dx.doi.org/10.1016/S0019-9958(65)90241-X.

Zadeh, L. A. (1975). The concept of a linguistic variable and its application to approximate reasoning-I. Information Sciences, 8(3), 199-249, doi:http://dx.doi.org/10.1016/0020-0255(75)90036-5. 
Appendix A. Profile of the interviews

\begin{tabular}{clll}
\hline No. & Organization & Respondent's functional position & Date (2013-2014) \\
\hline 1 & Mellat Bank & Head of Corporate Banking Division & 18 December \\
2 & Eghtesad Novin Bank & Head of Research and Planning Centre & 20 December \\
3 & Amin Investment Bank & Head of the Investment Bank & 25 December \\
4 & Omid Investment Bank & Head of the Investment Bank & 31 December \\
5 & Melli Bank & Member of Board of Directors & 8 January \\
6 & Omid Investment Bank & Head of Financial Risk Mgt. Division & 16 January \\
7 & Novin Investment Bank & Head of the Investment Bank & 22 January \\
8 & Melli Bank & Head of Retail Banking Division & 24 January \\
9 & Saman Bank & Member of Board of Directors & 30 January \\
10 & Novin Investment Bank & Head of Financial Risk and Controlling & 5 February \\
11 & Sepehr Investment Bank & Director, Research and Development & 9 February \\
12 & Saman Bank & Member of Board of Directors & 12 February \\
13 & Amin Investment Bank & Head the Investment Bank & 14 February \\
14 & Sepehr Investment Bank & Director, Risk Analysis and Mgt. Division & 20 February \\
15 & Corporate Client \#1* & Director, CFO Division & 28 February \\
16 & Corporate Client \#2* & Head of Strategic Management & 3 March \\
17 & Corporate Client \#3* & Director, CFO Division & 6 March \\
18 & Corporate Client \#4* & Director, CFO Division & 10 March \\
19 & Investor representatives\#1 & - & 18 March \\
20 & Investor representatives\#2* & - & 23 March \\
21 & Investor representatives\#3* & - & 25 March \\
22 & Investor representatives\#4* & - & 28 March \\
* To maintain confidentiality of the information entrusted by the nominated banks and investment banks to the authors, names \\
of corporate clients and investor representatives are not revealed in this study.
\end{tabular}


Appendix B. Interview protocol: Corporate client's perspective

\begin{tabular}{ll}
\hline Interview info & Respondent's information: \\
\hline Interview number: & Full name: \\
Date: & Age: \\
Time: & Position: \\
Location: & Working experience in finance (years): \\
Co-interviewer: & Years in current position:
\end{tabular}

\section{$\begin{array}{ll}\text { Guidelines and Questions } & \text { Observations }\end{array}$}

- Appreciating the respondent for his/her participation and appointment.

- Explaining the research purpose and scientific terms required to respond to the questions.

- Explaining the risks/benefits of participation.

- Explaining their withdrawal rights.

- Asking if they have any concerns/questions.

- Getting their permission to use the voice recorder.

- Turning on the voice recorder.

\section{A General info}

Q01 Please tell us about your main responsibilities (History, Products/ Services).

Please tell us about the tasks associated with your position relevant to

Q02 negotiating with underwriters and bank representatives (responsibilities, reporting, how many people you manage).

Describe situation(s), if any, which you considered to be adversely

Q03 affecting your relations with the corporate bank and/or bank that provides your company a variety of financial services.

Q04 Could you share your opinion about the core behavioral drivers that caused such situation(s)?

\section{B Stage I}

How much has the adverse situation(s) affected your manner of

Q05 cooperation with the underwriter and/or the bank in the bond underwriting processes? Please explain and prioritize.

Q06 How likely are you to choose the same bank and/or investment/corporate bank as your underwriter and issuer again? Please explain and prioritize.

\section{Stage II}

How much do you think the quality of relations between the bank and the

Q07 underwriter has caused the adverse situations that you experienced? Please explain and prioritize.

\section{Stage III}

How much do you think the quality of relations between the bank and the

Q08 investors has caused the adverse situations that you experienced? Please explain and prioritize.
[Main questions/answers]

\section{[Ice breaking and building rapport with the respondent]}

.


Figure 1. Corporate bond network

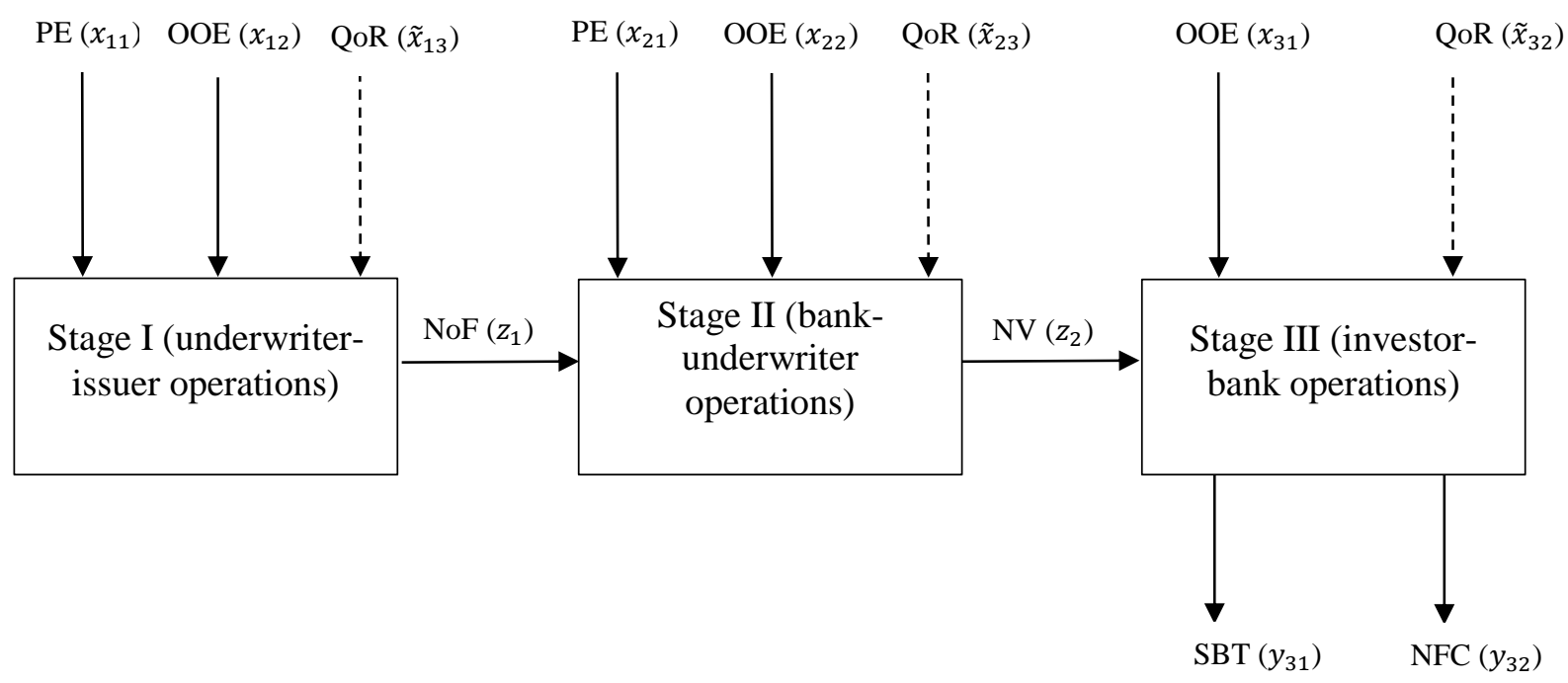

Legend: PE (personnel expenses), OOE (other operational expenses), QoR (quality of relations), NoF (number of referrals), NV (net value of issued bonds), SBT (proportion of sold bonds to total), NFC (net fees and commissions) 
Figure 2. Comparison of efficiency scores at $\alpha=1$ for corporate bond network with investment banks as underwriters

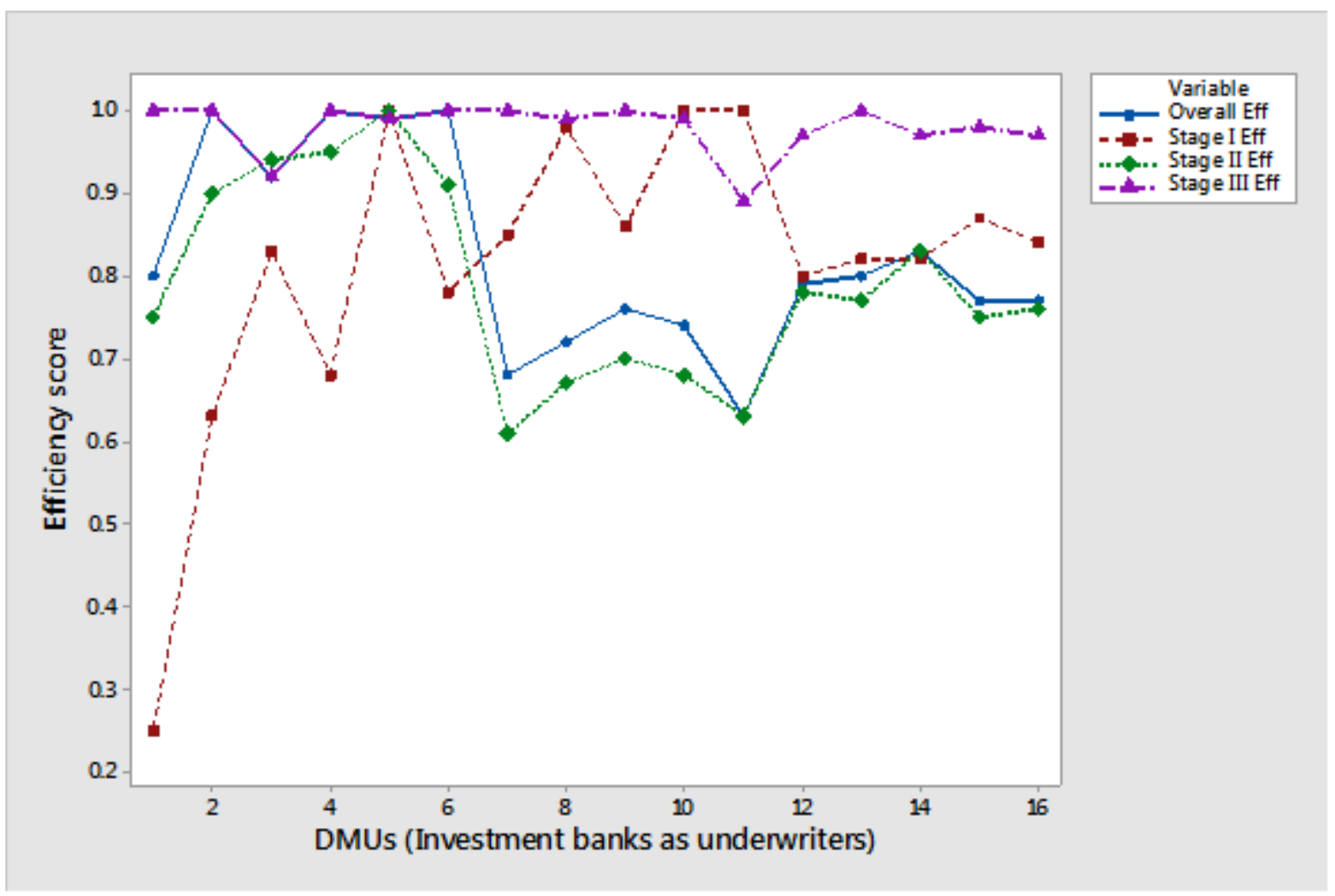

Figure 3. Comparison of efficiency scores at $\alpha=1$ for corporate bond network with corporate banks as underwriters

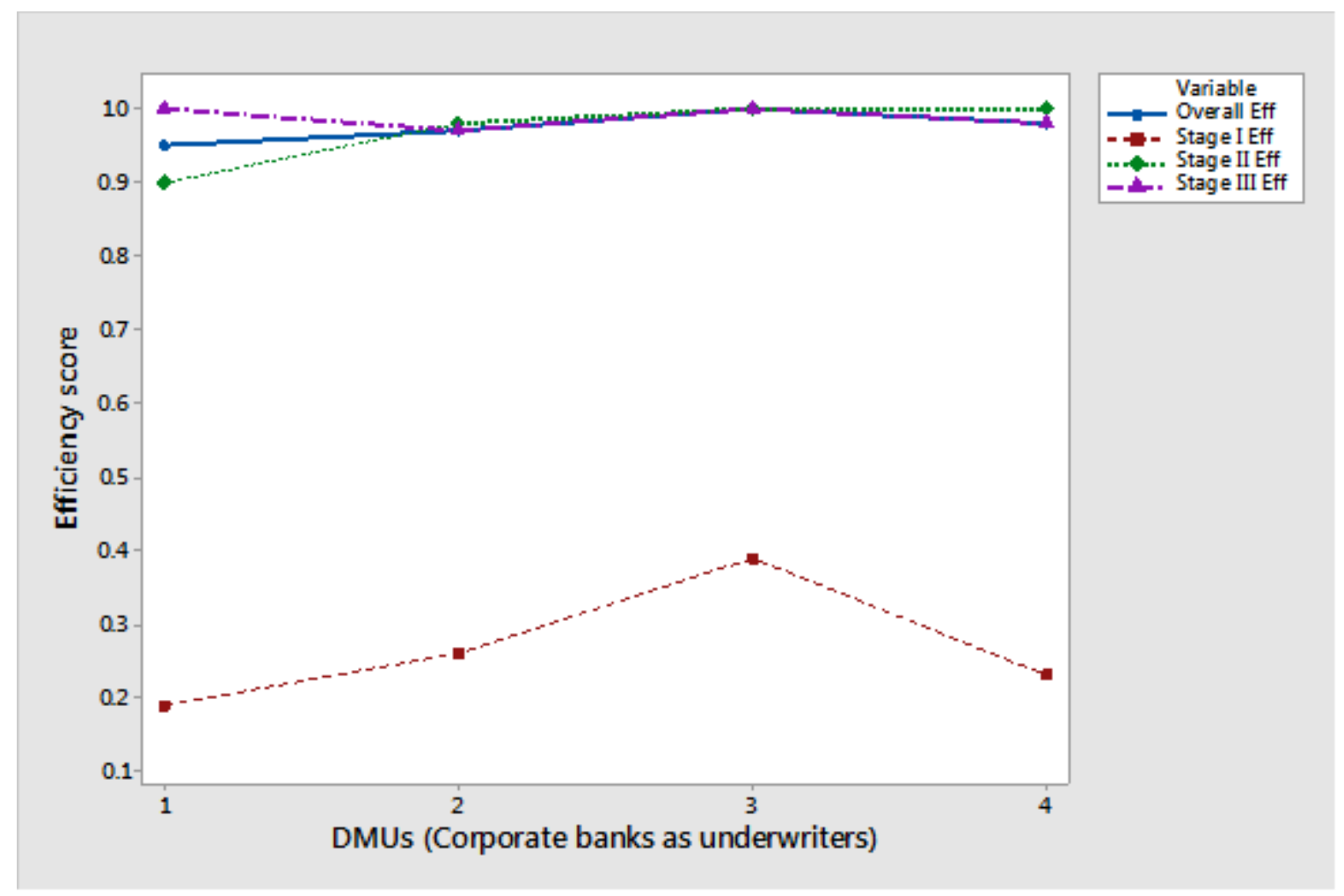


Table 1. Behavioral factors affecting quality of relations in the corporate bond network in three stages

\begin{tabular}{|c|c|c|c|c|c|c|c|c|}
\hline \multicolumn{3}{|c|}{ Stage I (underwriter-issuer operations) } & \multicolumn{3}{|c|}{ Stage II (bank-underwriter operations) } & \multicolumn{3}{|c|}{ Stage III (investor-bank operations) } \\
\hline Behavioral factor & Frequency & Possible cause & Behavioral factor & Frequency & Possible cause & $\begin{array}{l}\text { Behavioral } \\
\text { factor }\end{array}$ & Frequency & Possible cause \\
\hline Mistrust & $38 \%$ & $\begin{array}{l}\text { Anchoring of issuer } \\
\text { Opportunistic } \\
\text { behavior by } \\
\text { underwriter }\end{array}$ & Mistrust & $46 \%$ & $\begin{array}{l}\text { Anchoring of bank } \\
\text { Opportunistic } \\
\text { behavior by } \\
\text { underwriter }\end{array}$ & Mistrust & $42 \%$ & $\begin{array}{l}\text { Anchoring of } \\
\text { investor } \\
\text { Opportunistic } \\
\text { behavior by bank }\end{array}$ \\
\hline $\begin{array}{l}\text { Unethical and } \\
\text { unprofessional } \\
\text { behavior by the } \\
\text { issuer }\end{array}$ & $19 \%$ & $\begin{array}{l}\text { Lack of motivation, } \\
\text { feedback and } \\
\text { control on } \\
\text { underwriter's } \\
\text { employees }\end{array}$ & $\begin{array}{l}\text { Banks favoring } \\
\text { existing corporate } \\
\text { customers over } \\
\text { obtaining new } \\
\text { customers }\end{array}$ & $10 \%$ & $\begin{array}{l}\text { Loss aversion of } \\
\text { bank decision } \\
\text { makers }\end{array}$ & $\begin{array}{l}\text { Unethical and } \\
\text { unprofessional } \\
\text { behavior by the } \\
\text { bank }\end{array}$ & $22 \%$ & $\begin{array}{l}\text { Lack of } \\
\text { motivation, } \\
\text { feedback and } \\
\text { control on bank's } \\
\text { employees }\end{array}$ \\
\hline $\begin{array}{l}\text { Overestimating } \\
\text { financial stability } \\
\text { of issuer (default } \\
\text { risk) }\end{array}$ & $12 \%$ & $\begin{array}{l}\text { Overconfidence of } \\
\text { bank decision } \\
\text { makers } \\
\text { Information } \\
\text { avoidance of bank } \\
\text { decision makers } \\
\text { Sunk costs fallacy } \\
\text { of bank decision } \\
\text { makers }\end{array}$ & $\begin{array}{l}\text { Opportunistic } \\
\text { behavior of the } \\
\text { issuer }\end{array}$ & $10 \%$ & $\begin{array}{l}\text { Illusion of control } \\
\text { by banks decision } \\
\text { makers and lack of } \\
\text { sufficient } \\
\text { supervisory } \\
\text { mechanisms }\end{array}$ & $\begin{array}{l}\text { Investors' } \\
\text { unwillingness to } \\
\text { purchase the } \\
\text { bonds }\end{array}$ & $16 \%$ & $\begin{array}{l}\text { Conservatism of } \\
\text { investors } \\
\text { Risk aversion of } \\
\text { investors } \\
\text { Mistrust }\end{array}$ \\
\hline
\end{tabular}


Table 2. Efficiency scores of the corporate bond underwriting and issuance network

\begin{tabular}{|c|c|c|c|c|c|}
\hline DMU & Overall efficiency score & Overall & Stage I efficiency score & Stage II efficiency score & Stage III efficiency score \\
\hline \multicolumn{6}{|c|}{ DMUs with corporate banks as underwriters } \\
\hline $\mathrm{EN}^{a}$ Bank- EN Corporate Bank & $(0.94,0.95,0.99)$ & 8 & $(0.18,0.19,0.35)$ & $(0.9,0.9,0.96)$ & $(1,1,1)$ \\
\hline Mellat Bank - Mellat Corporate Bank & $(0.94,0.97,1)$ & 4 & $(0.26,0.26,0.27)$ & $(0.98,0.98,1)$ & $(0.95,0.97,1)$ \\
\hline Melli Bank- Melli Corporate Bank & $(0.96,1,1)$ & 2 & $(0.23,0.39,0.49)$ & $(0.97,1,1)$ & $(0.98,1,1)$ \\
\hline Saman Bank - Saman Corporate Bank & $(0.95,0.98,1)$ & 3 & $(0.23,0.23,0.40)$ & $(1,1,1)$ & $(0.95,0.98,1)$ \\
\hline Mean & $(0.95,0.98,1)$ & & $(0.23,0.27,0.38)$ & $(0.96,0.97,0.99)$ & $(0.97,0.99,1)$ \\
\hline Number of efficient DMUs & 0 & & 0 & 1 & 1 \\
\hline \multicolumn{6}{|c|}{ DMUs with investment banks as underwriters } \\
\hline EN Bank- Amin Investment Bank & $(0.80,0.80,0.93)$ & 12 & $(0.25,0.25,1)$ & $(0.75,0.75,0.89)$ & $(1,1,1)$ \\
\hline EN Bank- Novin Investment Bank & $(1,1,1)$ & 1 & $(0.54,0.63,0.63)$ & $(0.84,0.9,1)$ & $(1,1,1)$ \\
\hline EN Bank- Omid Investment Bank & $(0.83,0.92,1)$ & 9 & $(0.83,0.83,1)$ & $(0.94,0.94,1)$ & $(0.88,0.92,1)$ \\
\hline EN Bank- Sepehr Investment Bank & $(0.89,1,1)$ & 7 & $(0.68,0.68,1)$ & $(0.95,0.95,1)$ & $(0.93,1,1)$ \\
\hline Mellat Bank - Amin Investment Bank & $(0.91,0.99,1)$ & 5 & $(0.93,1,1)$ & $(1,1,1)$ & $(0.91,0.99,1)$ \\
\hline Mellat Bank - Novin Investment Bank & $(0.9,1,1)$ & 6 & $(0.78,0.78,1)$ & $(0.91,0.91,0.96)$ & $(0.97,1,1)$ \\
\hline Mellat Bank - Omid Investment Bank & $(0.67,0.68,0.71)$ & 20 & $(0.85,0.85,1)$ & $(0.61,0.61,0.61)$ & $(1,1,1)$ \\
\hline Mellat Bank - Sepehr Investment Bank & $(0.69,0.72,1)$ & 17 & $(0.97,0.98,1)$ & $(0.67,0.67,1)$ & $(0.93,0.99,1)$ \\
\hline Melli Bank - Amin Investment Bank & $(0.72,0.76,1)$ & 15 & $(0.85,0.86,1)$ & $(0.70,0.70,1)$ & $(0.95,1,1)$ \\
\hline Melli Bank - Novin Investment Bank & $(0.70,0.74,1)$ & 16 & $(1,1,1)$ & $(0.68,0.68,1)$ & $(0.94,0.99,1)$ \\
\hline Melli Bank - Omid Investment Bank & $(0.59,0.63,1)$ & 19 & $(1,1,1)$ & $(0.62,0.63,1)$ & $(0.84,0.89,1)$ \\
\hline Melli Bank - Sepehr Investment Bank & $(0.78,0.79,0.81)$ & 18 & $(0.80,0.80,1)$ & $(0.78,0.78,0.78)$ & $(.097,0.97,1)$ \\
\hline Saman Bank - Amin Investment Bank & $(0.78,0.80,1)$ & 11 & $(0.82,0.82,0.91)$ & $(0.77,0.77,0.78)$ & $(1,1,1)$ \\
\hline Saman Bank - Novin Investment Bank & $(0.80,0.83,1)$ & 10 & $(0.82,0.82,0.93)$ & $(0.83,0.83,1)$ & $(0.96,0.97,1)$ \\
\hline Saman Bank - Omid Investment Bank & $(0.74,0.77,1)$ & 13 & $(0.87,0.87,1)$ & $(0.75,0.75,0.75)$ & $(0.94,0.98,1)$ \\
\hline Saman Bank - Sepehr Investment Bank & $(0.74,0.77,1)$ & 13 & $(0.84,0.84,1)$ & $(0.76,0.76,1)$ & $(0.97,0.97,1)$ \\
\hline Mean & $(0.78,0.83,0.97)$ & & $(0.80,0.81,0.97)$ & $(0.79,0.79,0.92)$ & $(0.89,0.98,1)$ \\
\hline Number of efficient DMUs & 1 & & 2 & 1 & 4 \\
\hline Mann-Whitney U (Prob > X2, one- & $13.50(0.08)$ & & $2.00(0.00)^{b}$ & $6.50(0.01)^{b}$ & $30.00(0.89)$ \\
\hline Wilcoxon W (Prob > X2, one-tailed) & $149.50(0.08)$ & & $12.00(0.00)^{b}$ & $142.50(0.01)^{b}$ & $166.00(0.89)$ \\
\hline
\end{tabular}

${ }^{a}$ Eghtesad Novin

${ }^{b}$ Significant at 0.01 level 
Table 3. Forecast changes in inputs and outputs against the benchmark frontier (\%)

\begin{tabular}{|c|c|c|c|c|}
\hline \multicolumn{5}{|c|}{ Stage I (underwriter-issuer operations) } \\
\hline & Excess $\mathrm{PE}^{c}$ & Excess OOE & \multicolumn{2}{|l|}{ Excess QoR } \\
\hline Full sample & 0.00 & -1.30 & \multicolumn{2}{|l|}{-8.69} \\
\hline Subsample $1^{a}$ & 0.00 & -0.76 & \multicolumn{2}{|l|}{-10.62} \\
\hline Subsample $2^{b}$ & 0.00 & 0.00 & \multicolumn{2}{|l|}{-3.64} \\
\hline \multicolumn{5}{|c|}{ Stage II (bank-underwriter operations) } \\
\hline & Excess $\mathrm{PE}^{d}$ & Excess OOE & \multicolumn{2}{|l|}{ Excess QoR } \\
\hline Full sample & -0.44 & 0.00 & \multicolumn{2}{|l|}{-3.41} \\
\hline Subsample 1 & 0.00 & 0.00 & \multicolumn{2}{|l|}{-2.47} \\
\hline Subsample 2 & -0.85 & 0.00 & \multicolumn{2}{|l|}{-6.63} \\
\hline \multicolumn{5}{|c|}{ Stage III (investor-bank operations) } \\
\hline & Excess PE & Excess QoR & Shortage $\mathrm{SBT}^{e}$ & Shortage NFC \\
\hline Full sample & -1.22 & -1.22 & -3.66 & 2.55 \\
\hline Subsample 1 & -1.38 & -1.38 & -3.42 & 6.54 \\
\hline Subsample 2 & -1.37 & -1.37 & -2.00 & 6.43 \\
\hline \multicolumn{5}{|c|}{ a Sample with corporate banks as underwriters } \\
\hline \multicolumn{5}{|c|}{${ }^{b}$ Sample with investment banks as underwriters } \\
\hline \multicolumn{5}{|c|}{$\begin{array}{l}{ }^{c} \text { Excess indicates to percentage decrease in inputs and shortage indicates increase to outputs against efficient } \\
\text { frontier. }\end{array}$} \\
\hline \multicolumn{5}{|c|}{ Bold numbers illustrate the largest changes projected. } \\
\hline \multicolumn{5}{|c|}{${ }^{d} P E$ (personnel expenses), OOE (other operational expenses), QoR (quality of relations) } \\
\hline
\end{tabular}

